\title{
Bathypelagic particle flux signatures from a suboxic eddy in the oligotrophic tropical North Atlantic: production, sedimentation and preservation
}

\author{
Gerhard Fischer $^{1,2}$, Johannes Karstensen ${ }^{3}$, Oscar Romero ${ }^{2}$, Karl-Heinz Baumann ${ }^{1,2}$, Barbara Donner ${ }^{2}$, \\ Jens Hefter ${ }^{2,4}$, Gesine Mollenhauer ${ }^{2,4}$, Morten Iversen ${ }^{2,4}$, Björn Fiedler ${ }^{3}$, Ivanice Monteiro ${ }^{5}$, and Arne Körtzinger ${ }^{3}$ \\ ${ }^{1}$ Geosciences Department, University of Bremen, Klagenfurter Str., 28359 Bremen, Germany \\ ${ }^{2}$ Marum Centre for Marine Environmental Sciences, Leobener Str., University of Bremen, 28359 Bremen, Germany \\ ${ }^{3}$ GEOMAR Helmholtz Center for Ocean Research Kiel, Düsternbrooker Weg 20, 24105 Kiel, Germany \\ ${ }^{4}$ Alfred Wegener Institute, Helmholtz Center for Polar and Marine Sciences, 27570 Bremerhaven, Germany \\ ${ }^{5}$ Instituto Nacional de Desenvolvimento das Pescas (INDP), Cova da Inglesa, CP132, Mindelo, São Vicente, Cabo Verde
}

Correspondence to: Gerhard Fischer (gerhard.fischer@uni-bremen.de)

Received: 30 October 2015 - Published in Biogeosciences Discuss.: 13 November 2015

Revised: 28 April 2016 - Accepted: 13 May 2016 - Published: 2 June 2016

\begin{abstract}
Particle fluxes at the Cape Verde Ocean Observatory $(\mathrm{CVOO})$ in the eastern tropical North Atlantic for the period December 2009 until May 2011 are discussed based on bathypelagic sediment trap time-series data collected at 1290 and $3439 \mathrm{~m}$ water depth. The typically oligotrophic particle flux pattern with weak seasonality is modified by the appearance of a highly productive and low oxygen (minimum concentration below $2 \mu \mathrm{mol} \mathrm{kg} \mathrm{kg}^{-1}$ at $40 \mathrm{~m}$ depth) anticyclonic modewater eddy (ACME) in winter 2010. The eddy passage was accompanied by unusually high mass fluxes of up to $151 \mathrm{mg} \mathrm{m}^{-2} \mathrm{~d}^{-1}$, lasting from December 2009 to May 2010. Distinct biogenic silica (BSi) and organic carbon flux peaks of $\sim 15$ and $13.3 \mathrm{mg} \mathrm{m}^{-2} \mathrm{~d}^{-1}$, respectively, were observed in February-March 2010 when the eddy approached the CVOO. The flux of the lithogenic component, mostly mineral dust, was well correlated with that of organic carbon, in particular in the deep trap samples, suggesting a tight coupling. The lithogenic ballasting obviously resulted in high particle settling rates and, thus, a fast transfer of epi-/mesopelagic signatures to the bathypelagic traps. We suspect that the two- to three-fold increase in particle fluxes with depth as well as the tight coupling of mineral dust and organic carbon in the deep trap samples might be explained by particle focusing processes within the deeper part of the eddy. Molar $\mathrm{C}: \mathrm{N}$ ratios of organic matter during the ACME passage were around 18 and 25 for the upper and lower trap
\end{abstract}

samples, respectively. This suggests that some productivity under nutrient (nitrate) limitation occurred in the euphotic zone of the eddy in the beginning of 2010 or that a local nitrogen recycling took place. The $\delta^{15} \mathrm{~N}$ record showed a decrease from 5.21 to $3.11 \%$ from January to March 2010, while the organic carbon and nitrogen fluxes increased. The causes of enhanced sedimentation from the eddy in February/March 2010 remain elusive, but nutrient depletion and/or an increased availability of dust as a ballast mineral for organic-rich aggregates might have contributed. Rapid remineralisation of sinking organic-rich particles could have contributed to oxygen depletion at shallow depth. Although the eddy formed in the West African coastal area in summer 2009, no indications of coastal flux signatures (e.g. from diatoms) were found in the sediment trap samples, confirming the assumption that the suboxia developed within the eddy en route. However, we could not detect biomarkers indicative of the presence of anammox (anaerobic ammonia oxidation) bacteria or green sulfur bacteria thriving in photic zone suboxia/hypoxia, i.e. ladderane fatty acids and isorenieratene derivatives, respectively. This could indicate that suboxic conditions in the eddy had recently developed and/or the respective bacterial stocks had not yet reached detection thresholds. Another explanation is that the fast-sinking organic-rich particles produced in the surface layer did not interact with bacteria from the suboxic zone below. Carbon- 
ate fluxes dropped from $\sim 52$ to $21.4 \mathrm{mg} \mathrm{m}^{-2} \mathrm{~d}^{-1}$ from January to February 2010, respectively, mainly due to reduced contribution of shallow-dwelling planktonic foraminifera and pteropods. The deep-dwelling foraminifera Globorotalia menardii, however, showed a major flux peak in February 2010, most probably due to the suboxia/hypoxia. The low oxygen conditions forced at least some zooplankton to reduce diel vertical migration. Reduced "flux feeding" by zooplankton in the epipelagic could have contributed to the enhanced fluxes of organic materials to the bathypelagic traps during the eddy passage. Further studies are required on eddy-induced particle production and preservation processes and particle focusing.

\section{Introduction}

Time-series particle flux studies have been performed in many ocean areas, including typical oligotrophic settings in the Atlantic and the Pacific (Karl et al., 1996; Neuer et al., 2007; Lampitt and Antia, 1997; Honjo et al., 2008) and in eastern boundary upwelling ecosystems (EBUEs, Freon et al., 2009) (Fischer et al., 2010; Romero et al., 2002). In general, seasonality is low in areas with low primary production, while it increases towards coastal and open ocean high production (equatorial, polar) settings (Berger and Wefer, 1990; Romero and Armand, 2010). Mass fluxes at the French oligotrophic EUMELI site located north-west of the Cape Verde Ocean Observatory (CVOO) study site were rather low (mostly below $60 \mathrm{mg} \mathrm{m}^{-2} \mathrm{~d}^{-1}$ ), with a low to moderate seasonality (Bory et al., 2001).

In near-coastal areas, particle fluxes can vary dramatically due to productivity events triggered by upwelling and submesoscale frontal processes such as filaments (Fischer et al., 2009b). In the open ocean outside of frontal regions, productivity events are mostly related to the occurrence of mesoscale eddies (Benitez-Nelson and McGillicuddy, 2008). However, a flux signature from an eddy in the deep ocean has not yet been described using sediment traps or radionuclides (e.g. Buesseler et al., 2007). This might be due to undersampling and the episodic nature of pulses of organic matter from mesoscale eddies. In the quiescent shadow zone region of the eastern tropical North Atlantic (Luyten et al., 1983), mesoscale eddies originate mostly from energetic flow in the coastal/open ocean transition zone of the West African coast. After formation, the eddies propagate westward into the open North Atlantic, typically at certain latitudes which may be considered to be eddy corridors (Schütte et al., 2016a). The CVOO mooring site (Fig. 1), about $100 \mathrm{~km}$ north of the Cabo Verde island of São Vicente, is located in such an eddy corridor. Considering rotation as well as the vertical structure of eddies, three types may be distinguished (Schütte et al., 2016a): cyclonic, anticyclonic, and anticyclonic modewater eddies (ACMEs). In particular, ACMEs have been reported
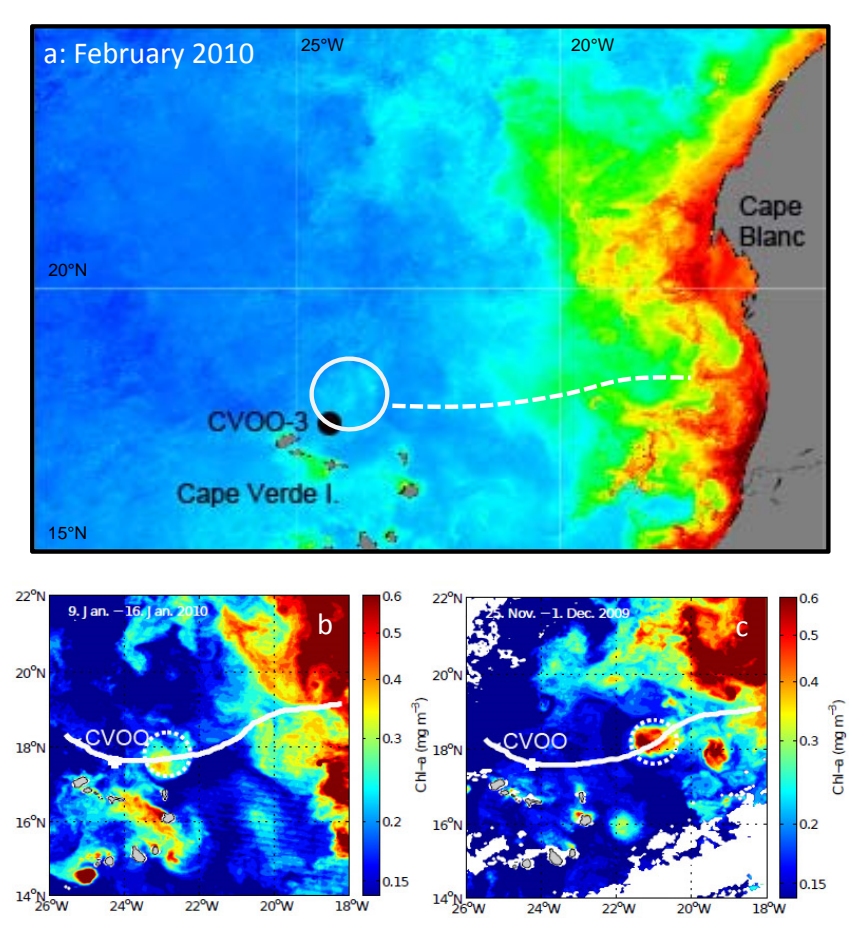

Figure 1. (a) MODIS high resolution chlorophyll picture $\left(4 \mathrm{~km}^{2}\right.$, L3) with the CVOO time-series site (black circle). Satellite chlorophyll within the ACME is low in February and hard to see (white circle). The pathway of the eddy from the coast to the CVOO site in summer 2009 is indicated by a white dashed line. (b, c) Satellite chlorophyll for November/December 2009 and January 2010 (modified, Karstensen et al., 2015). Chlorophyll decreased between November/December 2009 and January 2010, and again between January and February 2010 within the eddy.

in the past as supporting high productivity and chlorophyll standing stock, primarily related to a very shallow mixed layer base in the eddy and the efficiency in vertical transport of nutrients into the euphotic zone (McGillicuddy et al., 2007; Karstensen et al., 2016). A comprehensive overview of mesoscale eddies including ACMEs and their physical and biogeochemical linkages is given by Benitez-Nelson and McGillicuddy (2008). Multi-year oxygen time-series data from CVOO show frequent drops in oxygen concentration associated with the passage of ACMEs (Karstensen et al., 2015). One particularly strong event lasted the entire February 2010, with lowest oxygen concentrations of only 1$2 \mu \mathrm{mol} \mathrm{kg}-1$ at about $40 \mathrm{~m}$ depth (Karstensen et al., 2015). Using satellite data, the propagation path of this particular ACME has been reconstructed and found to have formed in summer 2009, at about $18^{\circ} \mathrm{N}$ at the West African coast (Fig. 1).

Here we describe particle flux signatures of the passage of this ACME crossing the CVOO in February 2010. We used monthly catches (29-day intervals) from bathypelagic sediment traps for the period from December 2009 to March 2011 (Table 1). The total length of the sediment trap data 


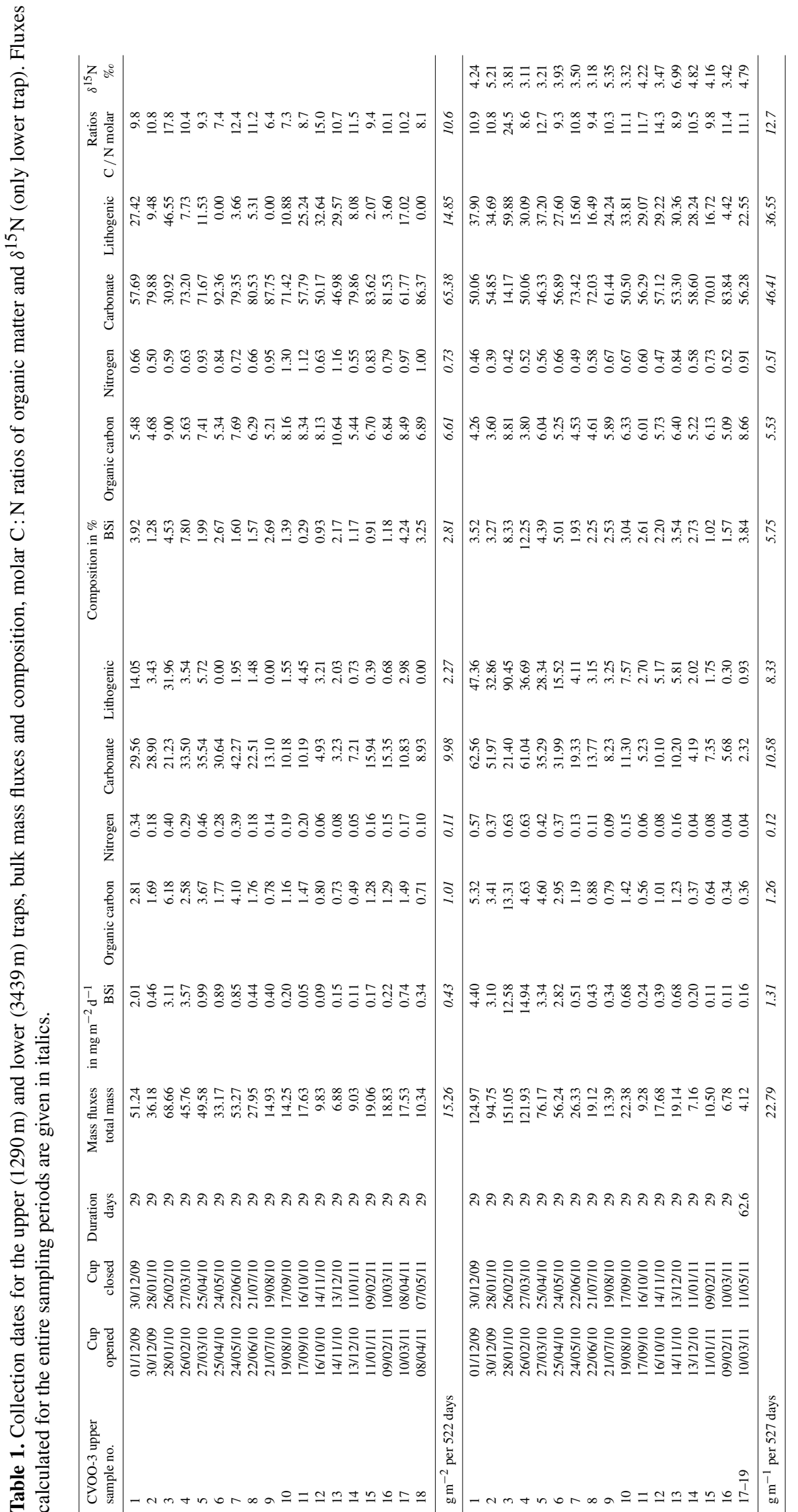


time series of about 16 months allowed us to compare winter 2009-2010 with an ACME passage to winter 2010-2011 without an ACME passage in the vicinity of the mooring site.

\section{Oceanographic, biological and atmospheric setting at CVOO}

The Cape Verde Ocean Observatory (CVOO) is located in the oligotrophic North Atlantic, far west of the coastal upwelling of the Canary Current System (Barton et al., 1998), one of the major eastern boundary upwelling ecosystems (Fréon et al., 2009). A distinct hydrographic boundary exists northwest of CVOO, the Cape Verde Frontal Zone (CVFZ, Zenk et al., 1991), separating the eastern boundary shadow zone with sluggish flow, low oxygen and high nutrient waters from the well-ventilated, high oxygen and nutrient-poorer waters to the west. The different coastal upwelling systems within the Canary Current (CC) have recently been described by Cropper et al. (2014) with respect to production, phytoplankton standing stock and seasonality.

Monthly maps of surface chlorophyll concentrations derived from ocean colour data in the CVOO area showed mostly concentrations below $0.25 \mathrm{mg} \mathrm{m}^{-3}$ (Fig. 1). A slight increase in surface chlorophyll was observed during boreal winter months where concentrations of up to $0.5 \mathrm{mg} \mathrm{m}^{-3}$ were found. The high cloud coverage partly prohibits detailed analysis of the surface chlorophyll concentrations. From the few high resolution daily maps available during the CVOO-3 period (Fig. 1), locally enhanced surface chlorophyll can be identified that coincides with a westward propagation of mesoscale eddies, a phenomenon that has been reported before (e.g. Benitez-Nelson and McGillicuddy, 2008). The eddies form in spring and summer at the African coast, in the area between Cape Blanc and Cape Vert, Senegal, and propagate westward at about $5 \mathrm{~km}$ per day (Schütte et al., 2016a). Some of the eddies, in particular the ACMEs, exhibit low dissolved oxygen (DO) concentrations at very shallow depth (<40 m; Karstensen et al., 2015). During CVOO-3, one particular highly productive/low oxygen ACME passed the CVOO site over a period of about 1 month, in February 2010 (Figs. 1 and 3).

The ocean area off West Africa receives the highest supply of dust in the world (Schütz et al., 1981; Goudie and Middleton, 2001; Kaufman et al., 2005; Schepanski et al., 2009). Dust is not only relevant for the climate system (e.g. Ansmann et al. 2011; Moulin et al., 1997) and the addition of nitrate, phosphate and iron to the surface ocean (e.g. Jickells et al., 1998), but also for the ballasting of organic-rich particles (Ittekkot, 1993; Armstrong et al., 2002; Iversen and Ploug, 2010; Ploug et al., 2008; Fischer and Karakas, 2009; Bressac et al., 2014) formed in the surface ocean. Lithogenic material attributed to mineral dust has been shown to contribute between $1 / 3$ and $1 / 2$ to the total deep ocean mass flux off Cape Blanc and south of Cabo Verde (CV-1-2 trap, ca. $11^{\circ} 30^{\prime} \mathrm{N}, 21^{\circ} \mathrm{W}$; Ratmeyer et al., 1999), respectively. Typically, mineral dust flux correlates with the satellitebased annual aerosol optical index (Fischer et al., 2010). High dust fluxes have been found at the oligotrophic EUMELI site far north of the CVOO (Bory et al., 2001). Fischer et al. (2009a) obtained a mean annual lithogenic (dust) flux of $14 \mathrm{~g} \mathrm{~m}^{-2} \mathrm{yr}^{-1}$ for the eastern North Atlantic off West Africa. Seasonality, mass concentrations and long-term chemical characterisation of Saharan dust/aerosols over the Cabo Verde islands based on the Cape Verde Atmospheric Observatory (CVAO) were described by Fomba et al. (2014).

\section{Material and methods}

\subsection{The Cape Verde Ocean Observatory (CVOO)}

The in situ observations used in this study have been acquired at the CVOO, located in the eastern tropical North Atlantic $\left(17^{\circ} 35^{\prime} \mathrm{N}, 24^{\circ} 15^{\prime} \mathrm{W}\right.$, Fig. 1) ca. $800 \mathrm{~km}$ west of the African coast and about $80 \mathrm{~km}$ north of the Cabo Verde islands. The site consists of a mooring ( $3600 \mathrm{~m}$ water depth) that was first deployed in September 2006 and has been operational since then. The sediment trap data were acquired at two depths during the deployment period October 2009 to May 2011 (CVOO-3). The mooring is equipped with a set of core sensors for hydrography (temperature, salinity sensors at different depth), currents (profiling in the upper $100 \mathrm{~m}$ and single rotor current meter (RCM-8) instruments at approximately 600, 1300, and $3400 \mathrm{~m}$ depth), and oxygen (typically two single sensors at 50 and $180 \mathrm{~m}$ depth). For analysis of the currents, we considered data from one current meter at $588 \mathrm{~m}$, one at $1320 \mathrm{~m}$ ( $30 \mathrm{~m}$ below the upper trap), and the deepest at $3473 \mathrm{~m}$ ( $46 \mathrm{~m}$ below the lower trap). For the $588 \mathrm{~m}$ and the upper trap RCM, complete time series of speed and direction are available. For the lower trap RCM, because of a rotor failure, only current direction but no current speed is available after mid-December 2009. RCM-8 current meters have a speed threshold $<2 \mathrm{~cm} \mathrm{~s}^{-1}$ and measure speed with $\pm 1 \mathrm{~cm} \mathrm{~s}^{-1}$ or $2 \%$ of measured speed (whatever is larger). Speed data $<1.1 \mathrm{~cm} \mathrm{~s}^{-1}$ have been set to the threshold of $1.1 \mathrm{~cm} \mathrm{~s}^{-1}$. Compass accuracy is $\pm 7.5^{\circ}$ for speed $<5 \mathrm{~cm} \mathrm{~s}^{-1}$ and $5^{\circ}$ above that threshold.

\subsection{Sediment traps and bulk particle flux analyses}

Particle fluxes were acquired using two cone-shaped and large-aperture sediment traps $\left(0.5 \mathrm{~m}^{2}\right.$; Kiel type; Kremling et al., 1996) at 1290 and $3439 \mathrm{~m}$, respectively. We collected sinking material with bathypelagic traps to circumvent flux biases such as undersampling due to strong ocean currents and/or zooplankton activities (Buesseler et al., 2007; Boyd and Trull, 2007; Berelson, 2002; Yu et al., 2001). We used samples collected on roughly monthly intervals (every 29 days, Table 1). The traps were equipped with 20 cups, which were poisoned with $\mathrm{HgCl}_{2}$ before and after deployment by 
addition of $1 \mathrm{~mL}$ of a saturated $\mathrm{HgCl}_{2}$ solution in distilled water at $20^{\circ} \mathrm{C}$ per $100 \mathrm{~mL}$. Pure $\mathrm{NaCl}$ was used to increase the density in the cups prior to the deployments (final salinity was $40 \%$ o). Large swimmers were removed manually and/or by filtering carefully through a $1 \mathrm{~mm}$ sieve. Thus, all fluxes refer to the size fraction of $<1 \mathrm{~mm}$. The flux of the size fraction of particles $>1 \mathrm{~mm}$ was negligible. Samples were wetsplit in the home laboratory using a rotating McLANE wet splitter and freeze-dried. Additional method information is given elsewhere (Fischer and Wefer, 1991).

Sediment trap samples were analysed using freeze-dried homogenised material of $1 / 5$ wet splits. It was weighed for total mass and analysed for organic carbon, total nitrogen, carbonate and biogenic silica. Particulate organic carbon, total nitrogen and calcium carbonate were measured by combustion with a Vario EL III elemental analyser in the $\mathrm{CN}$ mode. Organic carbon was measured after removal of carbonate with $2 \mathrm{~N} \mathrm{HCl}$. The overall analytical precision based on internal lab standards was $2.8033 \pm 0.0337 \%$ for organic carbon and $0.3187 \% \pm 0.0082$ for nitrogen, respectively. Carbonate was determined by subtracting organic carbon from total carbon, the latter being measured by combustion without pre-treatment with $2 \mathrm{~N} \mathrm{HCl}$. Biogenic opal was determined with a sequential $1 \mathrm{M} \mathrm{NaOH}$-leaching method according to Müller and Schneider (1993). The precision of the overall method based on replicate analyses is between \pm 0.2 and $\pm 0.4 \%$. Lithogenic fluxes were calculated from total mass flux by subtracting the flux of carbonate, biogenic opal and 2 times the flux of TOC to approximate organic matter. As there is no river input in the study area, we assume that all non-biogenic (= lithogenic) material was supplied via atmospheric transport.

Deep ocean sediment traps collect material from a rather large catchment area, typically around $100 \mathrm{~km}$ in diameter or wider, depending on particle settling rates and ocean currents (Siegel and Deuser, 1997). Making use of current meter data records from the upper water column (600 and $1300 \mathrm{~m}$ ), the progressive vector diagrams (PVDs) showed that the collected material before the eddy passage was under the impact of a current from the north-west, while after the eddy passage the material was transported more from the south-west (Fig. 2). In general, the currents were about twice as strong at $600 \mathrm{~m}$ compared to the $1300 \mathrm{~m}$ depth, and remained mostly below $10 \mathrm{~cm} \mathrm{~s}^{-1}$.

\subsection{Siliceous phytoplankton studies}

For this study, 1/125 splits of the original samples were used. Samples were rinsed with distilled water and prepared for siliceous plankton studies following the method proposed by Schrader and Gersonde (1978). Qualitative and quantitative analyses were done at $\times 1000$ magnifications using a Zeiss ${ }^{\circledR}$ Axioscop with phase-contrast illumination (MARUM, Bremen, Germany). Counts were carried out on permanent slides of acid cleaned material (Mountex ${ }^{\circledR}$ mounting medium). De- pending on diatom valve abundances in each sample, several traverses across each slide were examined. The total number of counted valves ranged between 300 and 600. At least two cover slips per sample were scanned in this way. Diatom counting of replicate slides indicates that the analytical error of the concentration estimates is $\leq 15 \%$ (Schrader and Gersonde, 1978).

The resulting counts yielded abundance of individual diatom taxa as well as fluxes of diatom valves per $\mathrm{m}^{-2} \mathrm{~d}^{-1}$ calculated according to Sancetta and Calvert (1988), as follows:

$F=\frac{[N] \times[A / a] \times[V] \times[\text { Split }]}{[\text { days }] \times[D]}$,

where $[N]$ is the number of valves, in an area $[a]$, as a fraction of the total area of a petri dish $[A]$ and the dilution volume $[V]$ in $\mathrm{ml}$. This value is multiplied by the sample split [Split], representing the fraction of total material in the trap, and is then divided by the number of [days] of sample deployment and the trap collection area $[D]$.

\subsection{Coccolithophores studies}

For coccolith counts, wet split aliquots of each sample (1/25 of the $<1 \mathrm{~mm}$ fraction) were further split by means of a rotary sample divider (Fritsch, Laborette 27) using buffered tap water as the split medium. Studied splits ranged between 1/250 and $1 / 2500$, which were filtered onto polycarbonate membrane filters of $0.45 \mu \mathrm{m}$ pore size. The filters were dried at $40^{\circ} \mathrm{C}$ at least for $12 \mathrm{~h}$ before a randomly chosen small section was cut out and fixed on an aluminium stub, sputtered with gold/palladium. The coccolith analysis was carried out using a ZEISS scanning electron microscope at $10 \mathrm{kV}$ accelerating voltage. In general more than 500 coccoliths were counted on measured transects at a magnification of $3000 \times$.

\subsection{Calcareous zooplankton studies}

The mass flux of carbonate is mainly constituted of planktonic foraminifera, pteropods and nanofossils/coccolithophores. To determine the proportion of calcareous zooplankton, a $1 / 5$ split of the $<1 \mathrm{~mm}$ fraction was used to pick planktonic foraminifera and pteropods from the wet solution. The picking was done by hand with a pipette under a ZEISS Stemi 2000 microscope. Picked shells were rinsed three times with freshwater and dried at $50^{\circ} \mathrm{C}$ overnight. Total mass fluxes of pteropods and planktonic foraminifera were determined with an analytical balance and mass fluxes $\left(\mathrm{mg} \mathrm{m}^{-2} \mathrm{day}^{-1}\right)$ were calculated. The foraminiferal species composition was determined under a ZEISS V8 microscope. The fluxes of all species were given as individuals $\mathrm{m}^{-2}$ day $^{-1}$. 

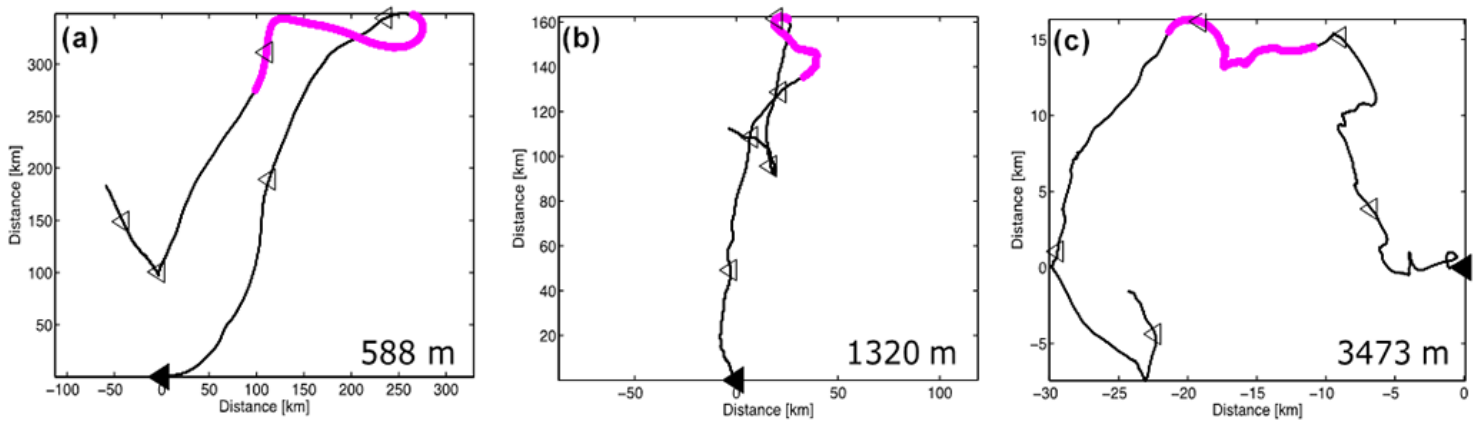

Figure 2. Progressive vector diagram (PVD) of $48 \mathrm{~h}$ low pass filtered current meter records at (a) $588 \mathrm{~m}$, (b) $1320 \mathrm{~m}$, and (c) $3473 \mathrm{~m}$ for the period from 1 December 2009 (filled triangle at 0.0) to 1 May 2010. The segment in each PVD that corresponds to the ACME passage is indicated by the magenta dots. Open triangles indicate the trap sampling intervals of 29 days. Note, for the deep trap current meter, that the speed failed shortly after installment, and a constant speed of $1.1 \mathrm{~cm} \mathrm{~s}^{-1}$ was used throughout the record.

\subsection{Stable nitrogen isotope ratios}

For the determination of the $\delta^{15} \mathrm{~N}$ of organic material, about $5 \mathrm{mg}$ of freeze-dried and homogenised material were used. The $\delta^{15} \mathrm{~N}$ was measured at the ZMT (Leibniz Center of Tropical Marine Ecology, Bremen). The Delta plus mass spectrometer is connected to a Carlo Erba Flash EA 1112 (Thermo Finnigan) elemental analyser via a Finnigan ConFloII interface. All of the data are expressed in the conventional delta $(\delta)$ notation, where the isotopic ratio of ${ }^{15} \mathrm{~N} /{ }^{14} \mathrm{~N}$ is expressed relative to air, which is defined as zero. The $\mathrm{N}_{2}$ reference gas was research grade and has been calibrated to air using IAEA-N1 and IAEA-N2. The internal standard used was pepton with a $\delta^{15} \mathrm{~N}$ value of $5.73 \pm 0.07 \%(1 \sigma)$.

\subsection{Biomarker studies}

Freeze-dried and homogenized samples (70-200 mg) were extracted three times with dichloromethane (DCM): methanol $(\mathrm{MeOH})$ 9:1 $(v / v)$ in an ultrasonic bath for $10 \mathrm{~min}$. Internal standards (squalane, $50 \mathrm{ng} /$ nonadecanone, $499.5 \mathrm{ng} / C_{46}$-GDGT, $500 \mathrm{ng}$ / erucic acid, $500.5 \mathrm{ng}$ ) were added prior to extraction. After centrifugation, solvents were decanted, combined and dried, and saponified $(2 \mathrm{~h}$, $80^{\circ} \mathrm{C}, 1 \mathrm{~mL} 0.1 \mathrm{M} \mathrm{KOH}$ in methanol : water $\left.(9: 1)\right)$. Neutral lipids (NLs) were extracted with $4 \times 0.5 \mathrm{~mL} n$-hexane. After acidification to $\mathrm{pH}<2(\mathrm{HCl})$, fatty acids were recovered with $4 \times 0.5 \mathrm{~mL} \mathrm{DCM}$ and esterified with methanolic $\mathrm{HCl}(12 \mathrm{~h}$, $80^{\circ} \mathrm{C}$ ). Silica-gel chromatography was used to separate $\mathrm{NL}$ into hydrocarbons (eluted with $n$-hexane), aromatic hydrocarbons ( $n$-hexane:DCM, 2:1), ketones (DCM:n-hexane, $2: 1)$ and polar compounds (DCM: $\mathrm{MeOH}, 1: 1$ ).

Alkenones were analysed using a 7890A gas chromatograph (Agilent Technologies) with a cold on-column (COC) injector, a DB-5MS fused silica capillary column $(60 \mathrm{~m}$, ID $250 \mu \mathrm{m}, 0.25 \mu \mathrm{m}$ film) and a flame ionisation detector (FID). Helium was used as a carrier gas (constant flow, $1.5 \mathrm{~mL} \mathrm{~min}^{-1}$ ) and the gas chromatograph (GC) was heated as follows: $60^{\circ} \mathrm{C}$ for $1 \mathrm{~min}, 20^{\circ} \mathrm{Cmin}^{-1}$ to $150{ }^{\circ} \mathrm{C}$, $6^{\circ} \mathrm{C} \mathrm{min}^{-1}$ to $320^{\circ} \mathrm{C}$, with final hold time $35 \mathrm{~min}$. Alkenone concentrations were calculated using the response factor of the internal standard (nonadecanone).

$U_{37}^{k^{\prime}}$ was calculated as defined by Prahl and Wakeham (1987):

$U_{37}^{k^{\prime}}=\frac{C_{37: 2}}{\left(C_{37: 2}+C_{37: 3}\right)}$,

and converted to sea surface temperatures (SSTs) using the calibration of Conte et al. (2006).

$T\left({ }^{\circ} \mathrm{C}\right)=-0.957+54.293\left(U_{37}^{k^{\prime}}\right)-52.894\left(U_{37}^{k^{\prime}}\right)^{2}+28.321\left(U_{37}^{k^{\prime}}\right)^{3}$

The aromatic as well as fatty acid methyl ester (FAME) fractions were analysed by gas chromatography/mass spectrometry for the presence of isorenieratene and its derivatives and ladderrane fatty acids.

\section{Results}

\subsection{Mass fluxes}

Mass fluxes increased in winter-spring 2009-2010 at both trap depths during the passage of the ACME at CVOO-3, but were rather low in winter-spring 2010-2011 (Fig. 3, Table 1). Fluxes were well correlated between both traps $\left(r^{2}=0.6, N=20\right)$, suggesting a fast transfer of the flux signature from the upper water column to bathypelagic depths. The lower trap fluxes were about twice as high as in the upper trap during the period of elevated fluxes in winter-spring 2009-2010. During winter 2010-2011, when no large eddy passed the CVOO study site, fluxes showed only a small seasonal increase, and the flux to the lower trap was lower in magnitude compared to winter-spring 2009-2010 (Fig. 3). We consider these to be the "normal conditions".

The flux pattern of biogenic silica (BSi) showed a more discrete peak than total mass, with maxima in FebruaryMarch 2010 (Fig. 4a). BSi fluxes were highest in March for 

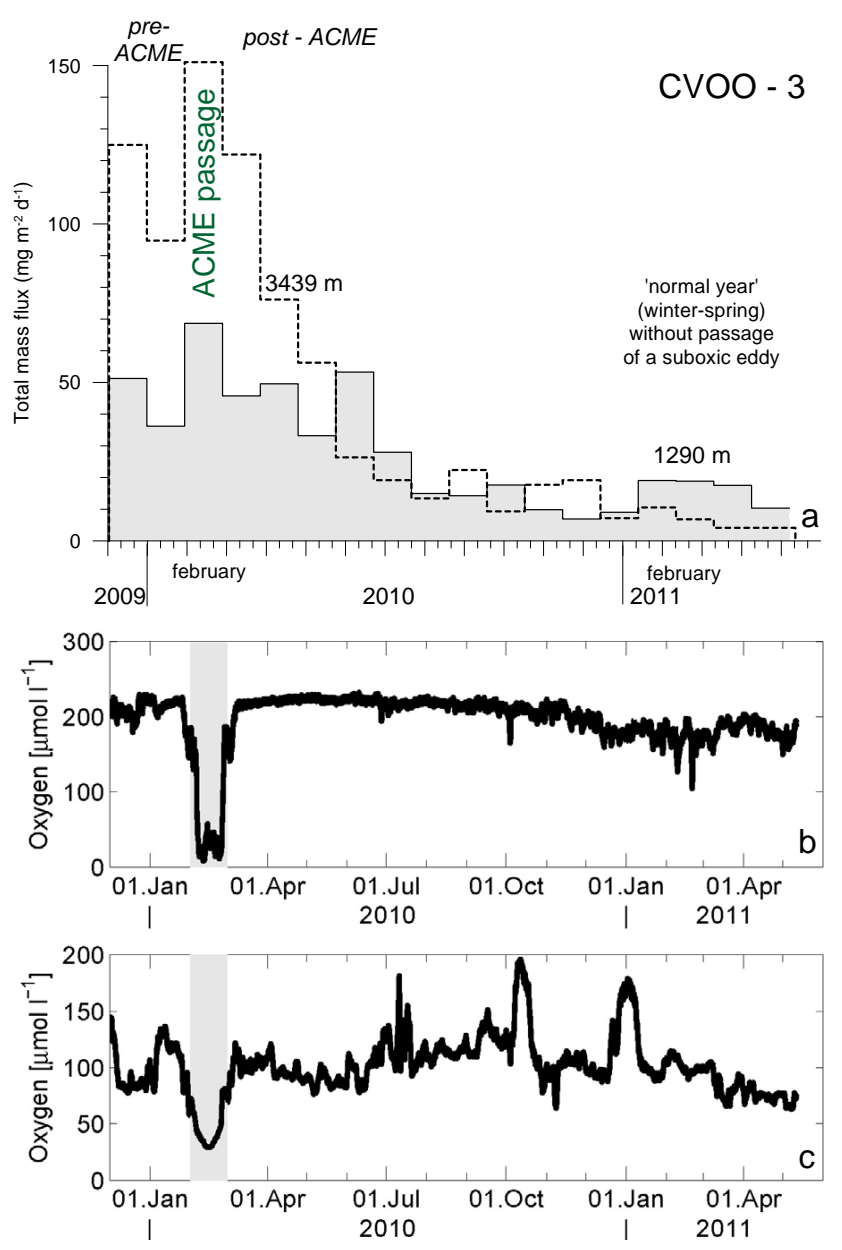

Figure 3. Total mass fluxes collected with the upper and lower sediment traps at CVOO-3 (a). Oxygen time series at approx. $42 \mathrm{~m}$ (b) and $170 \mathrm{~m}$ (c) water depths (Karstensen et al., 2015); grey bar indicates the ACME passage in February 2010. Upper and lower trap fluxes are highly correlated $\left(r^{2}=0.7 ; N=17\right)$; however, lower trap mass fluxes are roughly twice as high during winter-spring 2010 when the ACME passed the site. The common pattern can be seen in winter 2011 during the eddy-free year.

both traps and not in February when the ACME passed the study site. The high BSi fluxes arrived simultaneously at both trap depths without a time/cup lag. BSi fluxes were more than three-fold higher in the lower trap than in the upper trap during February-March 2010 (Fig. 4a). Very low BSi fluxes were measured in winter-spring 2011, and they were slightly higher in the upper trap. On an annual basis, the contribution of BSi to total flux mass was $2.8 \%$ (upper) and $5.75 \%$ (lower trap), respectively. However, during the ACME passage, the contribution increased significantly to $4.5-7.8 \%$ (upper) and $8.3-12.3 \%$ (lower trap) (Table 1). The opal fraction was mainly composed of marine diatoms. Organic carbon fluxes revealed a slightly different pattern from $\mathrm{BSi}$, with one distinct flux peak in February 2010 (Fig. 5a). Organic carbon fluxes in the deep trap were almost twice as high as those

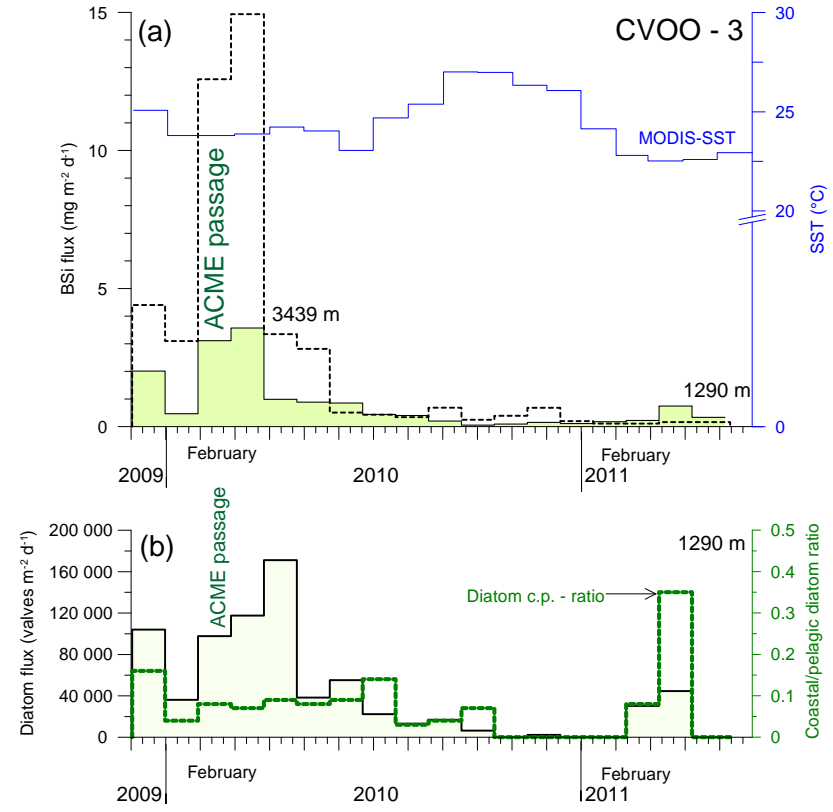

Figure 4. (a) BSi fluxes collected with the upper and lower sediment traps at CVOO-3. During the ACME passage in winter 2010, BSi fluxes were more than 3 times higher in the lower trap. Fluxes in both depth levels were highly correlated $\left(r^{2}=0.9, N=17\right)$. Monthly mean SST from MODIS-Terra- $4 \mathrm{~km}$ is shown for a $1^{\circ}$ box to the east of the CVOO-3 site $\left(17-18^{\circ} \mathrm{N}, 23-24^{\circ} \mathrm{W}\right)$. (b) Diatom fluxes and the coastal : pelagic diatom ratio are given for the upper trap samples.

collected in the upper trap during February 2010. In contrast, during the "normal conditions" in winter-spring 2011, organic carbon fluxes showed only minor differences between the upper and lower traps.

Lithogenic (mineral dust) fluxes were more than twice as high in the deep trap during the period influenced by the ACME passage (Fig. 6) and followed organic carbon flux with a distinct peak in February 2010. In particular, the deeper trap samples provided an almost perfect correlation between lithogenic material and organic carbon fluxes $\left(r^{2}=0.97, N=17\right)$. This correlation was less pronounced but still statistically significant for the upper trap samples $\left(r^{2}=0.63, N=18\right)$.

Total carbonate mass fluxes showed less seasonality than $\mathrm{BSi}$ and organic carbon, with broad maxima in winter-spring 2009-2010, largely following total mass (Figs. 3, 4, 5, 7). However, carbonate fluxes showed a decrease in February 2010 during the passage of the ACME, in particular in the deep trap. Fluxes of the major carbonate producers revealed a decrease in pteropod fluxes at both depths during FebruaryMarch 2010. Planktonic foraminifera, however, showed a clear flux peak in the deep trap during February 2010 and a rather broad increase in the entire winter-spring 2009 2010 in the upper trap (Fig. 7b). Total carbonate mass flux in winter-spring 2011 during "normal, non-eddy conditions" 


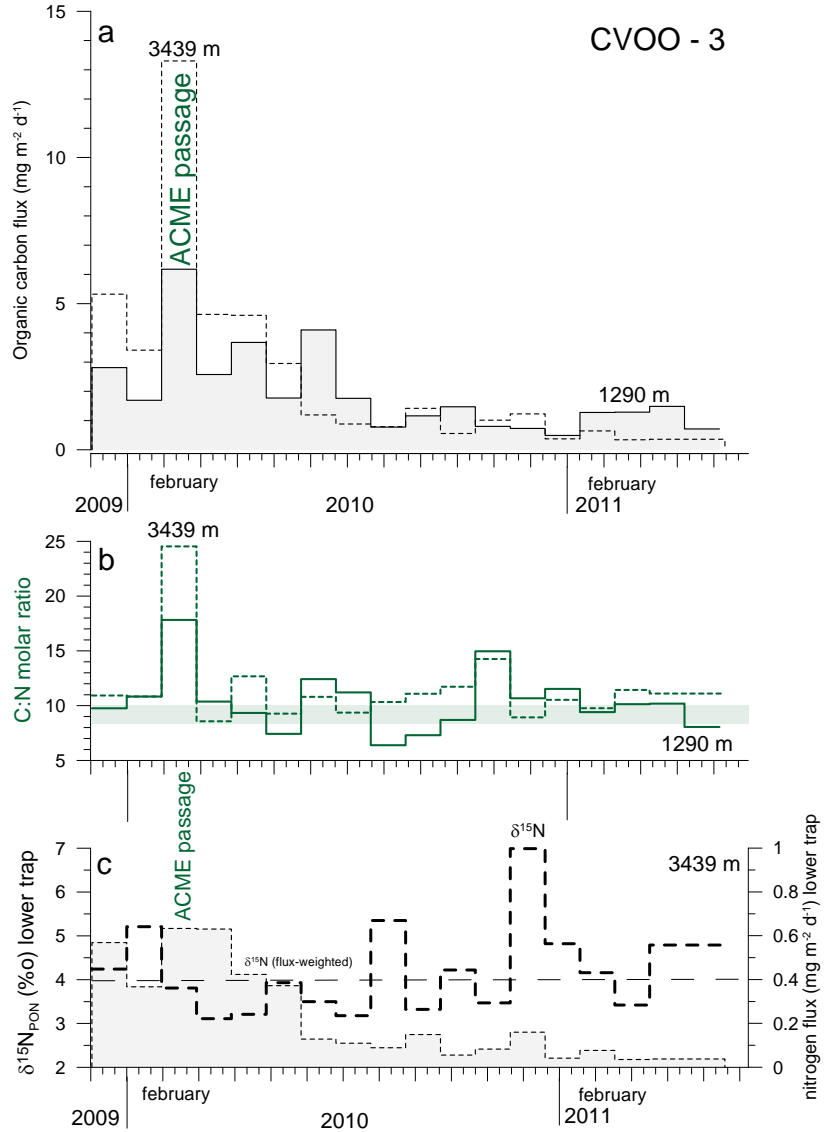

Figure 5. Organic carbon fluxes collected with the upper and lower sediment traps at CVOO-3 (a) and the corresponding molar $\mathrm{C}: \mathrm{N}$ ratios of the organic matter (b). Upper and lower trap fluxes are correlated $\left(r^{2}=0.7, N=17\right)$. Note the unusually high $\mathrm{C}: \mathrm{N}$ ratios in February 2010 recorded in both traps. Typical molar $C: N$ ratios (8-10) for degraded marine organic matter off north-western Africa (Fischer et al., 2003, 2010) are indicated by a green stippled horizontal bar in (b) and (c) $\delta^{15} \mathrm{~N}$ values for organic matter sampled by the lower trap (stippled thick line) shown together with the total nitrogen fluxes. The flux-weighted mean $\delta^{15} \mathrm{~N}$ value of 3.98 is shown as well.

was much lower than in 2010 and decreased between the upper and lower traps, which is typical for years without eddy passage.

\section{2 $\mathrm{C} / \mathrm{N}$ and $\delta^{15} \mathrm{~N}$ ratios}

The molar $\mathrm{C}: \mathrm{N}$ ratios of the organic material in both traps are rather high for deep ocean material compared to previous findings (Fischer et al., 2003, 2010). In February 2010, $\mathrm{C}: \mathrm{N}$ ratios were unusually high, with values around 18 and 25 in the upper and lower traps, respectively (Fig. 5b). The $\delta^{15} \mathrm{~N}$ ratios of the lower trap samples varied between 6.99 and $3.11 \%$ (Fig. 5c). The lowest value $(3.11 \%$ ) was measured following the passage of the ACME in February 2010, while the highest value of almost $7 \%$ was recorded in De-

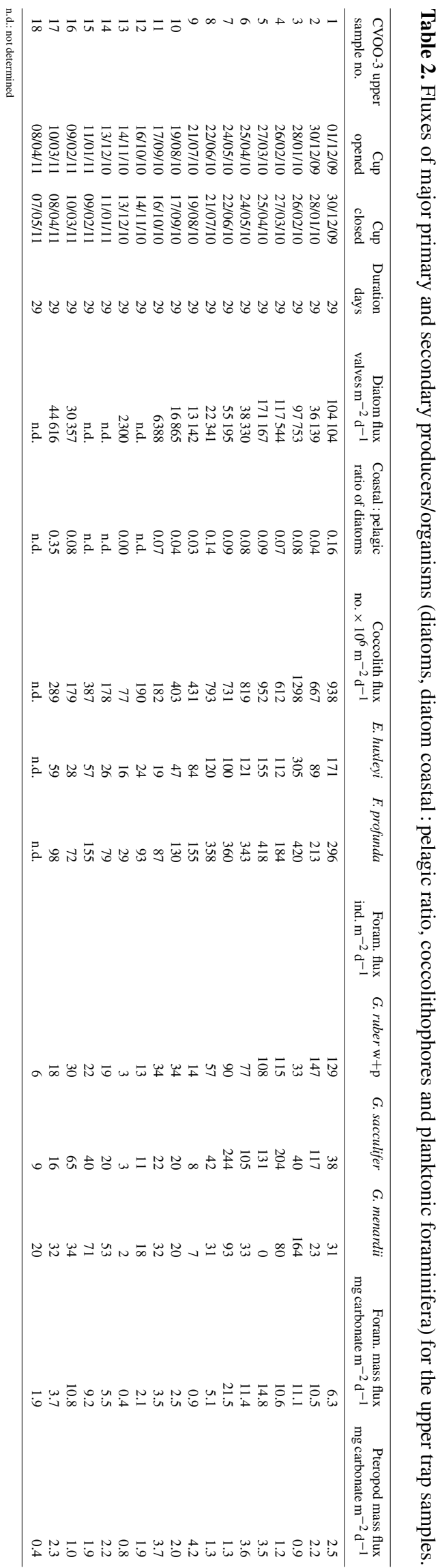

www.biogeosciences.net/13/3203/2016/ 


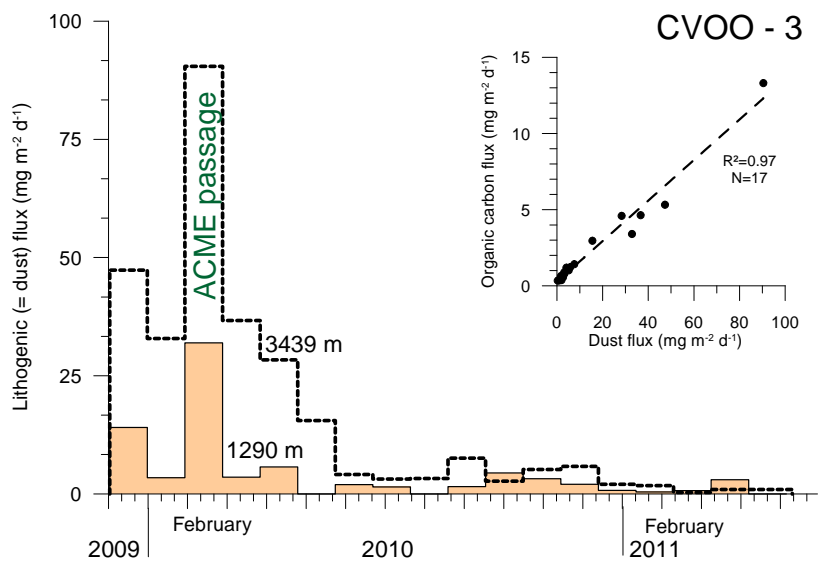

Figure 6. Lithogenic (mineral dust) fluxes collected with the upper and lower sediment traps at CVOO-3. Upper and lower trap fluxes correspond well $\left(r^{2}=0.83, N=17\right)$, but fluxes in the deep trap were more than twice as high compared to the upper trap during winter-spring when the ACME passed. Note the very close relationship with organic carbon $\left(r^{2}=0.97, N=17\right)$ shown for the deep trap samples (insert).

cember 2010. Distinct decreases were found from January to March 2010 (ACME passage), as well as from December 2010 to March 2011. The mean value was $4.16 \%$, the flux-weighted mean was, at $3.98 \%$, slightly lower. The $\delta^{15} \mathrm{~N}$ ratios were neither related to the $\mathrm{C}: \mathrm{N}$ ratios nor to the fluxes of nitrogen and carbon in general.

\subsection{Diatom fluxes}

The total diatom flux ranged from $2.3 \times 10^{3}$ to $1.7 \times 10^{5}$ valves $\mathrm{m}^{-2} \mathrm{~d}^{-1}$ in the upper trap (Fig. 4b; Table 2). One major diatom flux maximum $\left(>1.4 \times 10^{5}\right.$ valves $\left.\mathrm{m}^{-2} \mathrm{~d}^{-1}\right)$ occurred in mid-spring 2010 . The opal fraction was mainly composed of marine diatoms. In addition, silicoflagellates, radiolarians, freshwater diatoms, phytoliths and the dinoflagellate Actiniscus pentasterias occurred sporadically. In terms of number of individuals, diatoms dominated the opal fraction throughout the year: their flux was always 1 to 4 orders of magnitude higher than the flux of the other siliceous organisms encountered (not shown here). The diverse diatom community was composed of ca. 100 marine species. The most important contributors to the diatom community were species typical of open-ocean, oligo-to-mesotrophic waters of the low- and mid-latitude oceans: Nitzschia sicula, N. bicapitata, $N$. interruptestriata, $N$. capuluspalae, and Thalassionema nitzschioides var. parva. Resting spores of several coastal species of Chaetoceros, and tycoplanktonic/benthic Delphineis surirella, Neodelphineis indica and Pseudotriceratium punctatum, are secondary contributors.
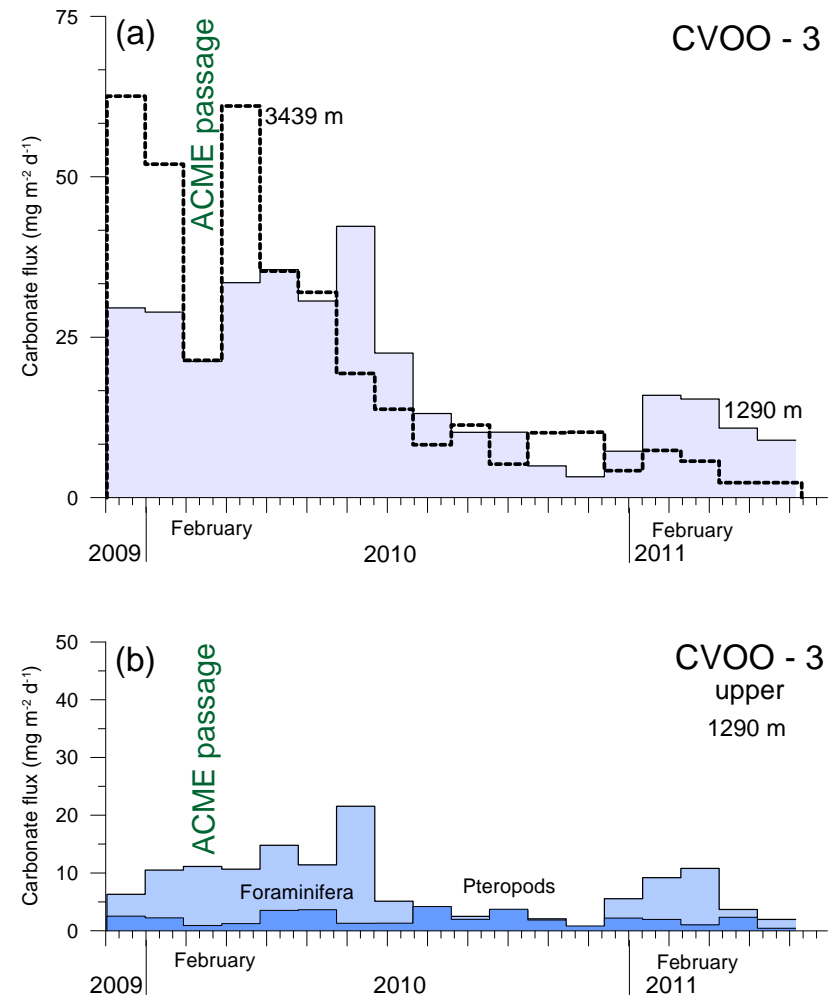

Figure 7. Carbonate fluxes collected with the upper and lower sediment trap (a) at CVOO-3 shown together with fluxes of planktonic foraminifera and pteropods (only upper trap data, (b), Table 2). Correlation of fluxes between both depths is less significant here compared to the other bulk components $\left(r^{2}=0.5, n=20\right)$. Note that total carbonate fluxes decreased during eddy passage in February 2010.

\subsection{Coccolith fluxes}

In general, both traps revealed coccolith fluxes that were high during the interval December 2009 to May 2010, whereas fluxes were considerably lower (ca. 2-10 times) during the rest of the studied period (Fig. 8a; Table 2). Maximum total coccolith fluxes were recorded in February 2010 for both traps, reaching values of $1300 \times 10^{6}$ coccoliths $\mathrm{m}^{-2} \mathrm{~d}^{-1}$ (upper trap, Fig. 8a) and $2880 \times 10^{6}$ coccoliths $\mathrm{m}^{-2} \mathrm{~d}^{-1}$ (lower trap, not shown), respectively. Total coccolith fluxes in the lower trap were generally $2-3$ times higher than in the upper trap. In total, 56 coccolithophore species were identified. The coccolithophores were generally dominated by lower photic zone (LPZ) species, such as Florisphaera profunda and Gladiolithus flabellatus, together with more omnipresent species such as Emiliania huxleyi and Gephyrocapsa spp. Florisphaera profunda that constituted between 21.7 and $49.2 \%$ of the total assemblage, and cosmopolitan E. huxleyi ranged between 13.4 and $29.4 \%$. Coccolith fluxes as well as $\%$ abundances of $F$. profunda slightly decreased in January-March 2010, although this species shows a distinct flux peak in February (Fig. 8a). In contrast, fluxes of E. hux- 

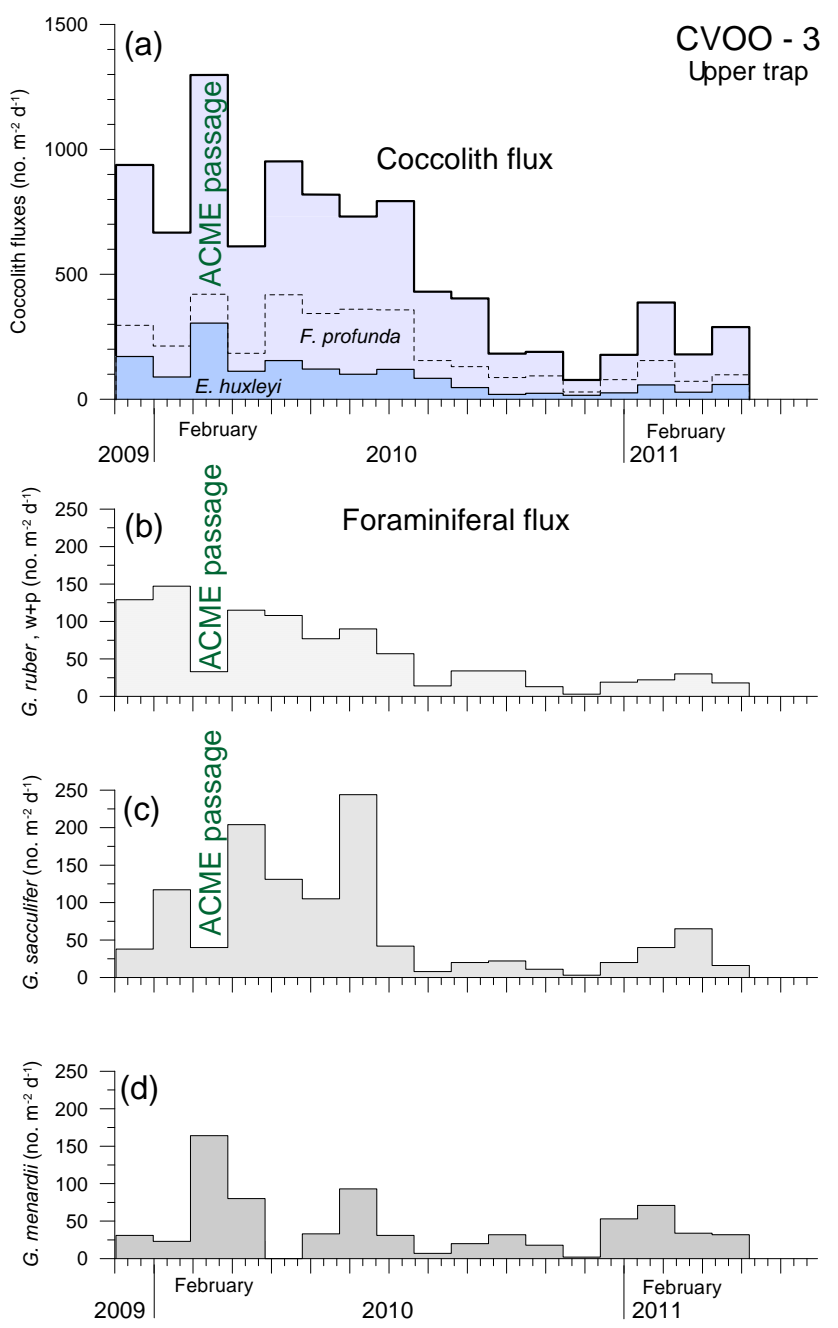

Figure 8. Upper trap fluxes of major primary and secondary carbonate producing organisms (Table 2). (a) Coccolithophores (total coccolith flux, flux of E. huxleyi and F. profunda). The planktonic foraminifera (b) G. ruber (white and pink), (c) G. sacculifer and (d) the deep-dwelling G. menardii, the latter showing a distinct peak in flux during the ACME passage in February 2010.

leyi as well as their relative proportion clearly increased during the interval February-March 2010 (Fig. 8a). Other taxa that considerably contributed to the assemblage are Gephyrocapsa ericsonii (2.3-16.7\%), G. oceanica (0.9-6.7\%), G. muellerae (0.3-14.0\%) and Umbilicosphaera sibogae (1.1$6.7 \%)$, which all show a pattern generally similar to that of $E$. huxleyi. In contrast, deep-dwelling G. flabellatus (1.3-7.3\%) and upper zone species Umbellosphaera tenuis (1.3-5.3\%) tend to show less prominent fluxes in February 2010 during the ACME passage. Other, more oligotrophic species ( $U$. irregularis, $R$. clavigera) display a similar pattern.

\subsection{Flux of planktonic foraminifera}

Planktonic foraminifera showed a clear flux peak in February 2010 in the deep trap (not shown) and a rather broad increase over the entire winter-spring season in 2010 at the upper trap level (Fig. 7b; Table 2). The surface dwellers and warm water species Globigerinoides ruber white and pink and Globigerinoides sacculifer were the three dominant species in the total foraminifer flux in both the upper (Fig. 8b, c) and deeper traps throughout. In February 2010, during the passage of the ACME, however, all three species exhibit a decrease in occurrence. During this interval, they were replaced by the subsurface dweller Globorotalia menardii, dominating the foraminiferal flux at both trap levels (Fig. 8d, only upper trap shown). The deep dwellers were generally rare at the CVOO-3 site; either they were missing almost completely (Globorotalia truncatulinoides) or they were present in low numbers. Globorotalia crassaformis, for instance, showed a flux pattern with a maximum in April-May in both trap levels, following the ACME passage in February 2010.

\subsection{Lipid biomarkers}

A reduced sample set from the upper trap, covering the sample period from December 2009 to July 2010 (samples $1-8$ ), was used for investigation of the organic biomarker composition and the characterisation of the ACME passage. Alkenone-derived $U_{37}^{k^{\prime}}$ values, a biomarker-based proxy for SSTs, varied from 0.82 to 0.98 , with the minimum value occurring in March, following the ACME passage (Table 3). Translation of the index into absolute temperatures by using the Conte et al. (2006) global calibration for surface particulate matter resulted in SSTs from 23.6 to $28.0^{\circ} \mathrm{C}$ (Fig. 9). From December 2009 to the end of March 2010, SSTs decreased from 26.5 to $23.6^{\circ} \mathrm{C}$. After the ACME passage, starting in April 2010, SSTs shifted back to around $28.0^{\circ} \mathrm{C}$. Alkenone fluxes (Fig. 9) showed a distinct six- to eight-fold increase during the ACME passage and correlate with organic carbon flux (Fig. 5a) and the molar $\mathrm{C}: \mathrm{N}$ ratios of organic matter (Fig. 9, $r^{2}=0.77, n=8$ ). The relationship between alkenone and total coccolith fluxes, however, is weak (Figs. 8a and 9). Unique membrane lipids of anammox bacteria, so-called ladderanes (Sinninghe Damsté et al., 2002) or biomarkers related to a pigment of the photosynthetic green sulfur bacteria Chlorobiaceae, isorenieratene and its derivatives, all indicative of photic zone anoxia, could not be detected using the analytical tools described above.

\section{Discussion}

\subsection{Production and export within the surface layer of the eddy}

The upper CVOO-3 trap revealed a rather unusual high BSi flux in winter-spring (around $4 \mathrm{mg} \mathrm{m}^{-2} \mathrm{~d}^{-1}$; Fig. 4a) which 
Table 3. Fluxes of alkenones, the $U_{37}^{k^{\prime}}$-unsaturation index and the estimated SSTs for samples $1-8$ of the upper trap.

\begin{tabular}{lrrrrrr}
\hline $\begin{array}{l}\text { CVOO-3 upper } \\
\text { sample no. }\end{array}$ & Cup open & Cup closed & $\begin{array}{r}\text { Duration } \\
\text { days }\end{array}$ & $\begin{array}{r}\text { Alkenone flux } \\
\mathrm{ng} \mathrm{m}^{-2} \mathrm{~d}^{-1}\end{array}$ & $\begin{array}{r}\text { Alkenone } \\
\text { unsat. ind. UK'37 }\end{array}$ & $\begin{array}{r}\text { Alkenone } \\
\text { SST }\left({ }^{\circ} \mathrm{C}\right)\end{array}$ \\
\hline 1 & $01 / 12 / 09$ & $30 / 12 / 09$ & 29 & 312.7 & 0.93 & 26.5 \\
2 & $30 / 12 / 09$ & $28 / 01 / 10$ & 29 & 209.5 & 0.91 & 25.9 \\
3 & $28 / 01 / 10$ & $26 / 02 / 10$ & 29 & 1852.5 & 0.85 & 24.3 \\
4 & $26 / 02 / 10$ & $27 / 03 / 10$ & 29 & 700.0 & 0.82 & 23.6 \\
5 & $27 / 03 / 10$ & $25 / 04 / 10$ & 29 & 464.2 & 0.91 & 26.1 \\
6 & $25 / 04 / 10$ & $24 / 05 / 10$ & 29 & 227.1 & 0.90 & 25.7 \\
7 & $24 / 05 / 10$ & $22 / 06 / 10$ & 29 & 1537.2 & 0.96 & 27.4 \\
8 & $22 / 06 / 10$ & $21 / 07 / 10$ & 29 & 791.2 & 0.98 & 28.0 \\
$9-18$ & & & & n.d. & n.d. & n.d. \\
\hline
\end{tabular}

n.d.: not determined

was partly higher than at the more coastal and mesotrophic Cape Blanc site CB (Fischer et al., 2003). The latter site is located within the Giant Cape Blanc filament and is characterised by high chlorophyll streaming offshore (Van Camp et al., 1991; Helmke et al., 2005). We argue that the unusually high BSi flux during the eddy passage was due to diatom production within the surface waters of the ACME. The diatom flux pattern revealed a distinct increase in February 2010, with a major peak later in early spring (Fig. 4b). The base of the mixed layer that coincides with the nutricline (Karstensen et al., 2016) shoaled from about 50-60 m before (and after) the eddy passage to about $20 \mathrm{~m}$ during the eddy passage (Karstensen et al., 2015). Elevated chlorophyll within the eddy is seen (Fig. 1) and has been discussed in the context of upward nutrient fluxes into the euphotic zone, particularly associated with ACMEs (e.g. Karstensen et al., 2015; Benitez-Nelson and McGillicuddy, 2008). Considering the timing of the distinct BSi and diatom flux signals, this may indicate that the organic carbon is primarily fixed on the western side of the eddy where an intense bloom is expected (Chelton et al., 2011). Sargasso Sea ACMEs, for instance, contain significant numbers of diatoms, regardless of the age of the eddy (McNeil et al., 1999; Sweeney et al., 2003; Ewart et al., 2008).

The molar $\mathrm{C}: \mathrm{N}$ ratios of organic matter were unusually high in February 2010 for both trap depths (Fig. 5b). They clearly fall far off the range of deep-ocean sediment trap samples or surface sediments with partly degraded organic marine material (C:N around 8-10; Fischer et al., 2003, 2010; $\mathrm{C}: \mathrm{N}=5-10$, Tyson, 1995; Wagner and Dupont, 1999). The exceptionally high ratios in February 2010 (C : N = 18 (upper) and 25 (lower trap)) (Fig. 5b), however, cannot be explained by mixing processes of marine $(\mathrm{C}: \mathrm{N}$ around the Redfield ratio, Redfield et al., 1963; Martiny et al., 2013) and terrestrial organic materials ( $\mathrm{C}: \mathrm{N}$ global mean $=24$, Romankevich, 1984), because this would imply a preferential contribution of terrestrial organic matter. On the one hand, nitrogen (nitrate) limitation in the surface water north of

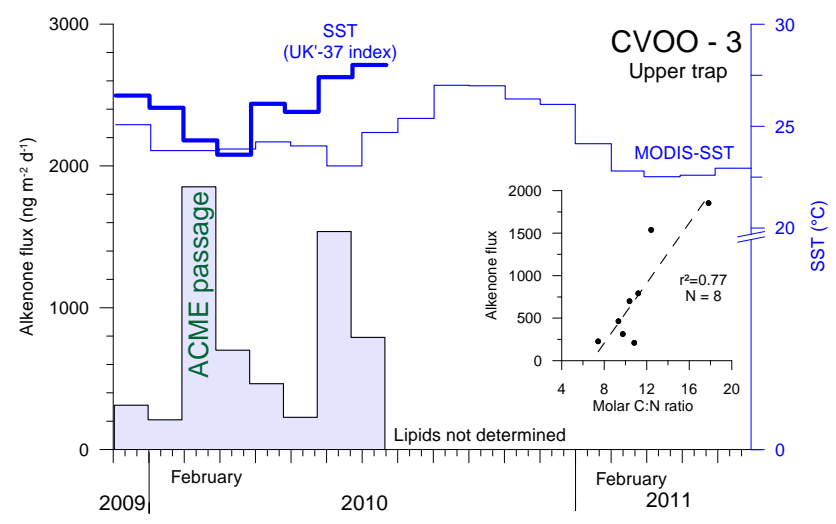

Figure 9. Alkenone fluxes together with the $U_{37}^{k^{\prime}}$-derived and satellite SSTs, for the time period before and after the ACME passage. Molar C : N ratios taken from Fig. 5b, which correlate well with the alkenone fluxes, are shown in the insert $\left(r^{2}=0.77, N=8\right)$.

the Cabo Verde islands combined with low growth rates of the primary producers (both diatoms and coccolithophores) would explain the elevated $\mathrm{C}: \mathrm{N}$ ratios of organic matter (e.g. Laws and Bannister, 1980; Martiny et al., 2013; Löscher et al., 2015a). However, since oxygen : nitrate ratios are about twice as high in the eddy compared to the surrounding waters, enhanced nitrogen recycling could explain the extraordinarily high $\mathrm{C}: \mathrm{N}$ ratios as well (Karstensen et al., 2016).

Nitrogen limitation is also known to increase the $\mathrm{C}: \mathrm{N}$ ratios of the alkenone producers (e.g. Loebl et al., 2010), and might result in an increase in the production and storage of alkenones (e.g. Eltgroth et al., 2005; Prahl et al., 2003). Alkenone temperature records from the Subtropical Front at the Chatham Rise, south-western Pacific Ocean (Sikes et al., 2005), showed that biases occurred during times of highest lipid fluxes and low nutrient conditions in the surface mixed layer. When plotting the $\mathrm{C}: \mathrm{N}$ ratios vs. the alkenone fluxes of the upper trap samples, we indeed obtain a relationship (Fig. 9, $r^{2}=0.77, n=8$ ) which points to nutrient limitation 

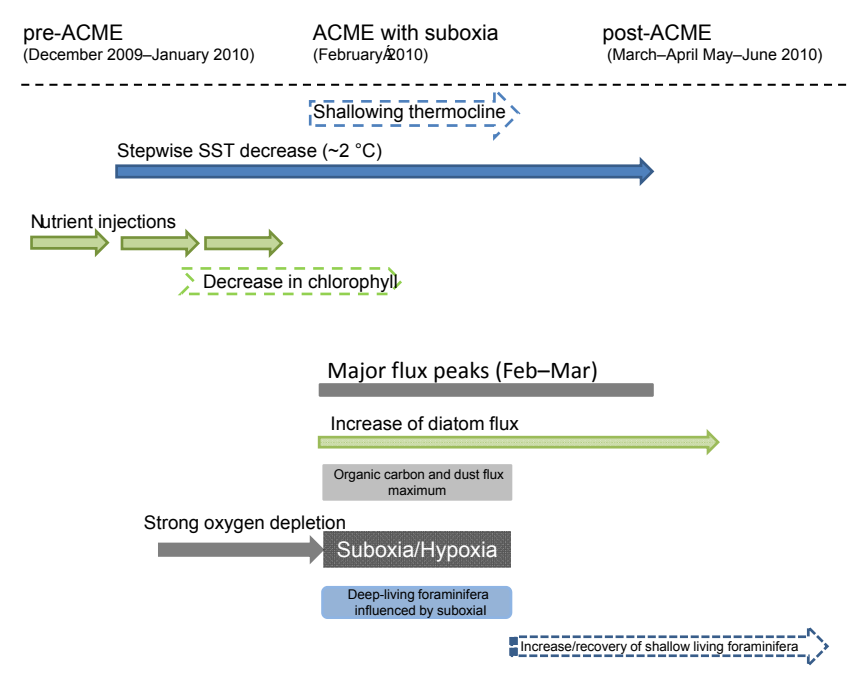

Figure 10. Schematic timeline of inferred processes within the ACME (surface waters and the anoxic/hypoxic water column below), which approached and passed the CVOO site in the beginning of 2010. Important sediment trap flux signatures are indicated. We assume a rapid transmission of the surface signature from the ACME to the bathypelagic sediment traps of only 1-3 weeks, mainly due to high particle settling rates.

during or shortly before the ACME passage. The CVOO-3 temperature record derived from the unsaturation index of the alkenones revealed a stepwise decrease in SST by about $2{ }^{\circ} \mathrm{C}$ (Fig. 9) from December 2009 to March 2010 (Fig. 10). However, these changes do not much differ from the general seasonal SST variability derived from satellite observations (Fig. 9).

The scenario of nutrient limitation within the surface water of the eddy is supported by elevated fluxes of BSi and organic carbon in February-March 2010 and agrees with chlorophyll decreases between November and December 2009 and between January and February 2010 (Fig. 1). However, since the sampling resolution is rather low (29 days), the traps cannot truly capture the high temporal dynamic biogeochemistry within the eddy and the resulting export fluxes, which may fluctuate within days and weeks. Secondly, variable settling rates of differently sized particles produced in the surface and subsurface waters of the eddy make it difficult to estimate the variable time lags between the responsible processes in the upper water column and the arrival of the flux signature in the bathypelagic traps.

The $\delta^{15} \mathrm{~N}$ ratios of the deep trap samples revealed a stepwise decrease (5.21 to $3.11 \%$ ) in winter 2009-2010 during the passage of the ACME as well as in winter 2010-2011 (6.99 to $3.45 \%$ o (Fig. 5c). The general pattern of $\delta^{15} \mathrm{~N}$ did not reveal any overall relationship between $\delta^{15} \mathrm{~N}$ ratios and nitrogen or organic carbon fluxes (Fig. 5a, c), as for example described for the oligotrophic Sargasso Sea (BATS, Altabet and Deuser, 1985). These authors found low $\delta^{15} \mathrm{~N}$ ratios (ca. $0 \%$ ) during times of highest organic carbon fluxes and elevated ratios (up to $3 \%$ ) with low fluxes. At CVOO-3, nitrogen and carbon fluxes increased and the $\delta^{15} \mathrm{~N}$ ratios decreased (Fig. 5) when the eddy passed the CVOO site. During the following non-eddy winter, $\delta^{15} \mathrm{~N}$ ratios were high (almost $7 \%$ ) at slightly elevated nitrogen flux, later decreasing with decreasing fluxes. Thus, there is no exceptional $\delta^{15} \mathrm{~N}$ pattern during the approach and passage of the ACME in 2010.

In general, $\delta^{15} \mathrm{~N}$ is high in temperate oceans after nitrate is depleted due to phytoplankton growth and low in more stable, oligotrophic seas (Saino and Hattori, 1987). Our $\delta^{15} \mathrm{~N}$ record in winter-spring 2009-2010 may reflect episodic nutrient injection into the euphotic zone of the ACME (Karstensen et al., 2015b), leading to increased particle formation and fluxes documented in February-March 2010 in the lower trap (Fig. 5c, Fig. 10). This nutrient injection from below can be deduced from a stepwise cooling starting in January 2010 and ending in March, as seen in the $U_{37}^{k^{\prime}}$ record (Fig. 9). The higher nitrogen fluxes were associated with a lowering of $\delta^{15} \mathrm{~N}$, as expected from other studies.

Under low oxygen conditions, denitrification by nitratereducing bacteria can affect the isotopic signature of the nitrate pool, leading to a significant enrichment of ${ }^{15} \mathrm{~N}$ in the residual nitrate pool relative to a deep water value of around 6\%o (Liu and Kaplan, 1989; Libes and Deuser, 1988). Our generally higher $\delta^{15} \mathrm{~N}$ ratios compared to the oligotrophic Sargasso Sea (Altabet and Deuser, 1985) may be partly explained by the injection of ${ }^{15} \mathrm{~N}$-enriched source waters within the ACME. From a high resolution nitrate/oxygen survey in low oxygen eddies, Karstensen et al. (2016) have clear indications of local nutrient recycling in the upper $200 \mathrm{~m}$. A rapid remineralisation of the sinking material releases dissolved nitrate at shallow depth while, in turn, part of this nitrate is returned to the surface layer by upwelling at the edge of the eddy. The upwelled nitrate is then incorporated into the sinking material produced in the surface layer of the eddy. As a consequence, one nitrate molecule can be used several times in the remineralisation process, which will not only lower the oxygen in the eddy core (underneath the productive zone), but potentially also enrich carbon. The single depth oxygen observations show minimal values below $2 \mu \mathrm{mol} \mathrm{kg}^{-1}$ in the eddy (Karstensen et al., 2015) and it is not unlikely that denitrification in the eddy will also alter the $\delta^{15} \mathrm{~N}$ to more positive values in the nitrate source waters (Liu and Kaplan, 1989). Löscher et al. (2015b) found a transcription of the key gene for denitrification in a low oxygen ACME in the Cabo Verde region studied in 2014.

The vertical distribution of many coccolithophore species is often controlled by upper photic-zone temperature and water stratification (e.g. Jordan and Chamberlain, 1997; Hagino et al., 2000). In particular, E. huxleyi is known to preferentially thrive in more turbulent and nutrient-enriched waters as found in upwelling areas or coastal regions (e.g. Haidar and Thierstein, 2001; Hagino and Okada, 2006; Boeckel and Baumann, 2008). Thus, the increasing fluxes during 
February-March 2010 (Fig. 8a) correspond well to nutrientenriched conditions during this time interval or somewhat before. Alkenones, synthesised by planktonic algae such as coccolithophorids, show a peak in flux during this time interval (Fig. 9). These observations correspond to nutrient measurements conducted in the low oxygen ACME in 2014 (Fiedler et al., 2016). The coccolithophore flora in the upper photic zone (UPZ) down to about $40-60 \mathrm{~m}$ are often composed of Umbellosphaera tenuis, U. irregularis, and Discosphaera tubifera, adapted to warm temperatures and low nutrient levels (e.g. Honjo and Okada, 1974; Hagino et al., 2000; Malinverno et al., 2003; Boeckel and Baumann, 2008). The same pattern is displayed by Rhabdosphaera clavigera, $R$. stylifer and Syracosphaera pulchra, all of which are nonplacoliths known to prefer stable stratified waters (Hagino et al., 2000). All these latter three species show a rather similar pattern, with slightly increased fluxes in February-March 2010 when the ACME passed. The species F. profunda and G. flabellatus are well established as species belonging to the lower-photic zone community (e.g. Honjo and Okada, 1974; Takahashi and Okada, 2000; Andruleit et al., 2003). In particular, $F$. profunda is known to occur exclusively in the deep photic zone (ca. 40-200 m), typically occurring at maximum abundances below the deep chlorophyll maximum in relatively high abundances (Haidar and Thierstein, 2001). During the ACME passage, we observed an increase in coccolith fluxes in February-March 2010 (Fig. 8a) and slightly less contribution of deeper-dwelling species such as $F$. profunda and G. flabellatus, probably due to the suboxia/hypoxia in the deeper water where these species thrive. However, a clear impact of the low oxygen conditions in the ACME on the photosynthetic coccolithophore community cannot be observed.

By comparing the fluxes in winter-early spring 2009-2010 under the influence of the ACME and the suboxia/hypoxia with winter-early spring 2011, when no larger eddy passed the CVOO site, the contribution of the ACME to annual mass flux can be estimated. This estimation does not consider interannual variability of absolute mass fluxes or changes in seasonality/timing of maxima from year to year and, therefore, has to be regarded as a first approximation. When comparing the organic carbon fluxes of the upper trap for the first four months of both years, we roughly obtain a three-fold increase in organic carbon flux when the eddy passed over the CVOO site compared to an eddy-free year (Fig. 5a). These estimates match rather well with data determined in the low oxygen ACME in 2014 (Löscher et al., 2015b). The latter authors obtained chlorophyll concentrations and carbon uptake rates within the eddy of up to 3 times as high as in the surrounding waters.

\subsection{Origin of hypoxia/suboxia and organic matter preservation within the eddy}

Neither the diatom nor the coccolithophore communities showed any significant influence of coastal waters in the collected materials. Given the surface ocean currents to the south-west at the CVOO site and the proximity to the northwestern African coast, it is reasonable to suspect that diatom blooms may have been due to a seed population from coastal waters. The diatom assemblage, however, shows no signature of coastal upwelling and benthic diatoms as indicators of entrained coastal waters. Low relative contributions of coastal upwelling-related resting spores of Chaetoceros (Romero et al., 2002) and a few benthic species, which thrive in nearshore waters above $50 \mathrm{~m}$ water depth (Round et al., 1990; Romero et al., 2015), suggest weak transport of plankton communities from near-shore/coastal waters into the pelagial north of the Cabo Verde islands. This east-to-west seaward transport neither carried substantial amounts of microorganisms nor vastly contributed to the pool of nutrients in waters overlying the CVOO site. Further evidence is provided by the coastal: pelagic ratio of the diatom assemblage of the upper trap (Fig. 4c). Compared to the values recorded at 200 nautical miles off Cape Blanc (Mauritania, CB trap site), the coastal: pelagic ratio of 20 to 25 at CVOO-3 is lower than values recorded at the $\mathrm{CB}$ site. At all times, the dominance of oceanic species at the CVOO-3 site reveals in situ diatom production with minor transport from the coastal realm. This indicates that the eddy at the time of its passage at CVOO-3 had significantly altered since its origin at the African coast at around $18^{\circ} \mathrm{N}$ in summer 2009 (Karstensen et al., 2015). At the origin of the ACME in summer 2009 off the West African coast, suboxia had not existed and oxygen was between 40 and $70 \mu \mathrm{mol} \mathrm{kg}^{-1}$ in the depth range of the later suboxic/hypoxic zone (40-170 m) in February 2010 (Karstensen et al., 2015). The severe suboxia/hypoxia in February 2010 therefore developed en route between summer 2009 and winter 2010. From satellite chlorophyll imagery (Karstensen et al., 2015) and high resolution MODIS data, the ACME approaching the CVOO site showed a decrease in chlorophyll between November/December 2009 and January and again between January and February 2010 (Fig. 1). In February 2010 a ring-like structure of rather low chlorophyll of approximately the size of the ACME remained within the oligotrophic surrounding area (Fig. 1a). However, a general high cloud cover renders satellite-based estimates difficult.

The elevated $\mathrm{C}: \mathrm{N}$ ratios in February 2010 found at both trap depths may be explained by nutrient limitation and slow growth rates of phytoplankton (e.g. Laws and Bannister, 1980; diatoms and coccolithophores) in the surface layer or by nitrogen recycling in the vicinity of the eddy (see Sect. 5.1). This could indicate that sedimentation of biogenic detritus started around the transition 2009-2010, matching the maxima of fluxes in February-March (Figs. 3$5,10)$. Using conservative estimates of particle settling rates of $200 \mathrm{~m} \mathrm{~d}^{-1}$, about 1-3 weeks are needed for sinking particles to travel down to the bathypelagic traps. The sinking detritus from the surface waters contributed to a lowering of the oxygen content in the upper layer of the eddy ("open ocean 
dead zone"; Karstensen et al., 2015). Consumption rates in these eddies and in the upper layer, where oxygen minima are created, have been found to be 3-5 times higher than in surrounding waters (Karstensen et al., 2015; Schütte et al., 2016b; Fiedler et al., 2016). Considering the chlorophyll decrease at the transition 2009-2010 (Fig. 1), we assume that the severe suboxia within the eddy was reached at the end of 2009/beginning of 2010 due to particle remineralisation (Fig. 10).

Screening of samples 1-8 of the upper trap for the presence of unique membrane lipids of anammox bacteria, socalled ladderanes (Sinninghe Damsté et al., 2002), did not provide evidence of the presence of such compounds during the ACME passage. Using the analytical protocol described above, we could not detect biomarkers related to a pigment of the photosynthetic green sulfur bacteria Chlorobiaceae, isorenieratene and its derivatives, all indicative of photic zone anoxia (e.g. Koopmans et al., 1996). Thus, evidence of bacterial communities detected in oxygen minimum zones (OMZs), including green sulfur bacteria and anammox bacteria (see summary in Löscher et al., 2015a), could not be found with our methods. However, detection of these compounds requires the respective bacterial stocks to be present in concentrations above a certain detection threshold and/or an effective export mechanism for them leading to incorporation into sinking particles. Although one might expect these compounds to be present during the ACME passage when low oxygen conditions prevailed in the subsurface waters (Löscher et al., 2015a), it is likely the populations have not reached significant levels, because suboxic conditions just recently developed within the eddy. Another possible explanation is that the bacteria were present in the suboxic zone of the eddy, but did not interact and were not attached to the fast-sinking organic-rich particles, which originated in the surface layer and later constituted the mass flux.

No signs of dissolution in sinking calcareous particles i.e. coccolithophores or foraminifera are seen, which might have occurred due to reduced $\mathrm{pH}$ within the suboxic/hypoxic parts of the eddy. The low oxygen ACME waters surveyed in 2014 had a pH of about 7.6 (Fiedler et al., 2016). No clear signs of carbonate dissolution could either point to a rapid transport of sinking carbonate particles through the suboxic/hypoxic water column of the ACME as outlined above or to some protection of carbonate particles by periotrophic membranes of fecal pellets or both.

\subsection{Mineral dust and particle settling rates}

In general, both traps revealed similar flux signals with maxima around February to March 2010 (Figs. 3-5, 10), matching the ACME passage. Considering the synchronicity of peaks in BSi and other bulk components, a fast vertical transport of the surface particle flux signature into the meso- and bathy-pelagic is expected within the eddy. Given the 29-day sampling interval of the traps, the particle set- tling rate for the bathypelagic water column should at least reach $150 \mathrm{md}^{-1}$, applying the methods described in Fischer and Karakas (2009) and Berelson (2002). Fischer and Karakas (2009) provided a compilation of particle settling rates with a mean of $235 \pm 71 \mathrm{~m} \mathrm{~d}^{-1}$, using several particle flux patterns from the mesotrophic Cape Blanc moorings, located in the EBUEs and, hence, closer to the coast. For the sediment trap mooring sites south of Cabo Verde (CV 1-2; Ratmeyer et al., 1999), an even higher mean sinking speed of $416 \mathrm{~m} \mathrm{~d}^{-1}$ was estimated (Fischer and Karakas, 2009). The latter authors argued that high organic carbon fluxes in the Canary Current compared to other EBUEs are at least partly due to high particle settling rates, which result in low carbon respiration rates (Iversen and Ploug, 2010), most probably favoured by a high ballast content.

Deep trap organic carbon fluxes plotted vs. the fluxes of lithogenic material (mineral dust) provided an exceptionally good empirical relationship $\left(r^{2}=0.97, N=17\right.$, Fig. 7), never observed before off north-western Africa (e.g. Fischer et al., 2010). For the upper trap samples, the correlation coefficient was lower $\left(r^{2}=0.63, N=18\right)$ but still statistically significant. This relationship, however, does not explain the complex processes involved in the formation of larger and fast-sinking settling particles in the surface and subsurface waters and the interaction of biogenic with non-biogenic particles. Le Moigne et al. (2014) pointed out that mineral ballast is not equally important for export in the ocean, but may be dependent on local ecology as well. Lab experiments with roller tanks and ballast minerals, however, clearly indicate the importance of mineral ballast for increasing sinking rates and lower carbon degradation within marine snow aggregates off north-western Africa (Ploug et al., 2008; Iversen and Ploug, 2010). Additional evidence is provided by observations gained during a field campaign in winter 2012 off Cape Blanc (eutrophic site CBi). Higher organic carbon fluxes at 100 and $400 \mathrm{~m}$ water depths using drifting traps were recorded, matching faster particle settling rates after a 1-2-day low-altitude dust storm event (Iversen et al., unpublished data). A simulated dust deposition event in a large mesocosm showed increased organic carbon fluxes as well (Bressac et al., 2014).

Besides the question of the development of suboxia/hypoxia within the eddy discussed above, the causes of enhanced sedimentation of biogenic detritus in FebruaryMarch are unclear. From our field studies in the Cape Blanc area (e.g. Fischer and Karakas, 2009) and lab studies with in situ chlorophyll and mineral dust (e.g. Iversen, unpublished; van der Jagt, unpublished), we speculate that Saharan mineral dust preferentially settling in winter in the Cape Blanc and Cabo Verde ocean area (e.g. Gama et al., 2015) might have contributed or even initiated particle settling via ballasting of organic-rich aggregates (Ploug et al., 2008; Iversen and Ploug, 2010; Iversen and Robert, 2015) produced within the chlorophyll-enriched eddy. Some effect on particle production and fluxes by fertilisation due to the input of macro- 
nutrients by dust (e.g. nitrogen; Fomba et al., 2014) via dust cannot be excluded.

The co-variation of fluxes of organic carbon and mineral dust (Fig. 6) suggests that both components settled in close association into the bathypelagial. In the high dust region south of Cabo Verde, Ratmeyer et al. (1999) obtained correlation coefficients of ca. 0.6 between lithogenic material (dust) and organic carbon in the deep traps. Time series of aerosol optical thickness (AOT, $869 \mathrm{~nm}, 9 \mathrm{~km}$ resolution) from MODIS did not show unexpectedly high values for dust concentration in the atmosphere above a 1 or $4^{\circ}$ grid over the CVOO site in early 2010. However, the AOT did not provide a true dust deposition rate at the ocean surface in winter 2010 at the study site. At the Cabo Verde islands, Fomba et al. (2014) and Gama et al. (2015) found highest aerosol/dust concentrations during winter, with distinct peaks between January and March when the eddy approached and passed the CVOO site. However, extraordinarily high dust concentrations early in 2010 were not recorded (Fomba et al., 2014).

\subsection{Zooplankton within the eddy and organic carbon degradation}

Acoustic backscatter data suggest that at least some zooplankters reduced their diel vertical migration behaviour in the low oxygen eddies (Karstensen et al., 2015; Hauss et al., 2016) but also in large-scale open ocean OMZs (e.g. Ayon et al., 2008). Mobile zooplankton such as certain copepods may escape from the low oxygen eddy core (e.g. ACME 2010), while certain less mobile protozoa such as planktonic foraminifera may be encountered by the suboxia, die and settle down. In a low oxygen eddy observed in spring 2014 at CVOO, acoustic backscatter data and multinet sampling indicated a compression of zooplankters in the surface waters with a high abundance of calanoid copepods and euphausiids (Hauss et al., 2016). This suggests a high grazing pressure on these organisms in the surface layer during eddy passage.

The flux patterns of planktonic foraminifera revealed a clear peak flux in February 2010 in the lower trap, matching the passage of the suboxic eddy. The subsurface (50-100 m water depth) dweller Globorotalia menardii largely responsible for this flux peak in the upper trap in February 2010 (Fig. 8d) is a tropical to subtropical non-spinose species with changing depth habitats (Hemleben et al., 1989). We assume that the oxygen within the ACME became too low in early 2010 and the more or less immobile G. menardii died, resulting in sedimentation and elevated fluxes in both trap levels. Foraminifera are generally assumed to settle with high rates of several hundreds to a few thousand metres per day (Kucera, 2007); thus, a clear flux signal without time delay is expected in the two bathypelagic traps. The near-surface dwellers Globigerinoides ruber pink and white and Globgerinoides sacculifer, on the other hand, showed a clear decline in flux in February 2010 in both trap samples (Fig. 8b, c), contributing to reduced total carbonate fluxes (Fig. 7). This pattern might be due to the shoaling of the mixed layer base from $50-60 \mathrm{~m}$ to about $20 \mathrm{~m}$ (Karstensen et al., 2015) and a decrease in SST (Fig. 9) during the ACME passage (Fig. 10). Foraminifera trapped in the uppermost water layer might have suffered from a high grazing pressure because of the low oxygen eddy core below. The foraminiferal peaks in the deeper trap in April-June 2010 were mostly due to high fluxes of $G$. sacculifer that followed the eddy passage. The increase in foraminiferal flux at both depths in AprilJune may represent a return to regular (non-eddy) conditions and a recovery/deepening of the mixed layer (Fig. 10). The actively migrating pteropods (Chang and Yen, 2012) show some decrease in the fluxes in February-March 2010 at both bathypelagic depths (Fig. 7b). This can be explained by the escape from the low oxygen zone of the approaching eddy and some sedimentation elsewhere.

Missing diel migration of a number of zooplankton groups due to the passage of the suboxic eddy (Karstensen et al., 2015; Hauss et al., 2016) could have resulted in less organic matter degradation of sinking particles due to reduced "flux feeding" within the suboxic/hypoxic zone (around 40$170 \mathrm{~m}$ ). This depth range is the most active zone in terms of organic carbon turnover under normal conditions with sufficient oxygen (e.g. Iversen et al., 2010; Hedges, 1992). Flux feeding may account for a large part of organic carbon degradation in the uppermost few hundred metres of the water column and determine the shape of the carbon attenuation curve (Iversen et al., 2010), although quantitative estimates are lacking. Under oxic conditions, overall carbon-specific respiration due to microbial degradation is estimated to be $0.13 \mathrm{~d}^{-1}$ in the uppermost ocean (Iversen and Ploug, 2010, 2013; Iversen et al., 2010), independent of particle size and type. It is likely that the severe hypoxia/suboxia reduced both oxic microbial respiration and zooplankton "flux feeding". As a result, the organic carbon flux to greater depths might have increased.

\subsection{Increase in mass fluxes with depths and flux focusing}

There is a significant increase in all bulk flux components with depth from December 2009 to May 2010. The organic carbon fluxes were twice as high in the deep than in the upper trap and well correlated $\left(r^{2}=0.70\right)$. BSi flux was more than three-fold higher at greater depth (correlation coefficient $r^{2}=0.91$ ) during the eddy passage. The flux of coccoliths increased with depth three-fold as well. For organic carbon, an overall decrease in flux with depth has to be expected (when excluding lateral advection), following an exponential equation in classical oceanic settings with sufficient oxygen in the water column (see summary in Boyd and Trull, 2007). Depending on the vertical shear and the predominant velocity direction at a different depth, it is not unlikely that that deeper traps collect more material than shallower ones (Siegel and Deuser, 1997). 
The mean currents at the CVOO site were sluggish, with monthly mean velocities between 2 and $6 \mathrm{~cm} \mathrm{~s}^{-1}$ (equivalent to 1.5 to $5.1 \mathrm{~km} \mathrm{~d}^{-1}$ ) for the RCM at thermocline depth $(588 \mathrm{~m})$ as well as for the upper trap, and thus being in the range of the propagation speed of the eddies (Schütte et al., 2016b). For the lower trap, values were below $2 \mathrm{~cm} \mathrm{~s}^{-1}$ $\left(1.7 \mathrm{~km} \mathrm{~d}^{-1}\right)$, also considering velocity data from previous deployments (March 2008 to October 2009, not shown here). Assuming a particle settling rate of $100 \mathrm{~m} \mathrm{~d}^{-1}$ and sluggish lateral flux $\left(2 \mathrm{~km} \mathrm{~d}^{-1}\right)$, the setting of a particle through a $3500 \mathrm{~m}$ water column will take about 35 days and the material is displaced by less than $100 \mathrm{~km}$. However, not only the speed but also the flow direction is of particular importance if the particle generation sites are characterised by spatial heterogeneity. We assume two primary source regions, the coastal upwelling region off West Africa approximately 300 to $700 \mathrm{~km}$ to the east of CVOO, and the local productivity oasis related to the eddy (Fig. 1). Comparing the progressive vector diagrams (PVDs) from three depths at CVOO-3 for the period December 2009 to May 2010, it is evident that the RCM in the thermocline (Fig. 2a) and the RCM close to the upper trap (Fig. 2b) are under the impact of a meridional transport from the south before and also after the eddy crossed the CVOO. In contrast, the lower trap with its higher catchment area was impacted by a more zonal transport from the east (Fig. 2c) and, thus, from where the eddy approached. Unfortunately, because of the rotor failure of the lower trap RCM, it is unclear how far the catchment area extended.

During the eddy passage, all three RCMs show varying currents, dominated by the local circulation associated with the eddy (Fig. 2). The nearest and most probable additional particle source area for the deep trap to the east and northeast is the approaching ACME. The flux within the eddy could therefore be laterally transported by the prevailing current system towards the deep trap (Fig. 2c), whereas the upper trap received material from the south (Fig. 2a, b). Whether this differential transport can account for a two- to three-fold increase in mass fluxes cannot be proven from the existing data. Considering the tight coupling of mineral dust fluxes with organic carbon fluxes for the deep trap samples (Fig. 6), it seems reasonable to assume that a particle focusing (concentration) mechanism contributed to the observed increase in fluxes with depth. Fine dust particles may move upwards within the eddy and interact with organic-rich particles to form marine snow aggregates. On the other hand, the eddy may operate as a twisted funnel with some downward movement of larger particles, e.g. at the eddy's boundary in its deeper part. There is a clear need for detailed studies on particle transport processes within different types of eddies and particle trajectories of approaching eddies (e.g. via Lagrangian particle experiments in numerical model velocity fields).

\section{Summary}

The impact of the passage of an anticyclonic modewater eddy (ACME) on the particle fluxes at the CVOO mooring site has been investigated from time-series sediment trap data from December 2009 to May 2011. The eddy passage over site CVOO was recorded in February 2010 and was characterised by very low $\left(<2 \mu \mathrm{mol} \mathrm{L}^{-1}\right)$ dissolved oxygen concentrations observed at a very shallow depth (about $40 \mathrm{~m}$, Karstensen et al., 2015). From the reconstructed propagation path of the eddy (Karstensen et al., 2015), satellite-derived chlorophyll maps reveal surface signatures of high chlorophyll standing stocks within the eddy (Fig. 1). With respect to the particle flux signatures, we identified a number of important processes and associated responses in the bathypelagic ocean (Fig. 10):

- compared to a non-eddy year 2011, BSi, diatoms and organic carbon fluxes increased and seasonality was unusually high in winter-spring 2010 when the ACME passed;

- organic carbon flux corresponded well to the lithogenic (mineral dust) flux, mainly in the deep trap. This suggests a close coupling between the eolian input and the biological pump;

- bulk mass fluxes were two- to three-fold higher in the deep compared to the upper trap. The predominant flow direction at the two depths may in part explain the discrepancy, but other mechanisms, e.g. particle focusing processes, have to be considered as well;

- diatoms showed no signature from coastal environments, suggesting a pronounced alteration since the eddy formation at the West African coast in summer 2009;

- molar $\mathrm{C}: \mathrm{N}$ ratios of organic matter were unusually high (18-25) in February 2010. Nutrient (nitrate) limitation might have occurred in the euphotic zone in the beginning of 2010. However, there is some evidence of local nitrogen recycling (Karstensen et al., 2016), which may increase the $\mathrm{C}: \mathrm{N}$ ratios as well. Moreover, local denitrification in the low oxygen eddy core (e.g. Löscher et al., 2015a) could contribute to increasing $\mathrm{C}: \mathrm{N}$ ratios;

- biomarkers provided no evidence of green sulfur bacteria or bacteria characteristic of anammox, both of which might be present under suboxic conditions or in OMZs;

$-\delta^{15} \mathrm{~N}$ ratios declined from 5.2 to $3.1 \%$ from January to March 2010 during the approaching and passing ACME, combined with a peak in nitrogen flux in February-March 2010;

- carbonate fluxes decreased in February 2010, mainly due to declining fluxes of pteropods and near-surfacedwelling planktonic foraminifera. Flux peaks of the 
subsurface dwellers G. menardii in February 2010 were most probably due to the development of low oxygen conditions in the subsurface waters of the ACME;

- coccolithophores as major primary carbonate producers appear to be less affected by the ACME passage. Nearsurface E. huxleyi and other species showed increased fluxes in February 2010;

- particle sedimentation out of the ACME might have occurred due to nutrient exhaustion and/or deposition of mineral dust in December 2009 and January 2010;

- no indication of carbonate dissolution due to a reduced $\mathrm{pH}(\sim 7.6$, Fiedler et al., 2015$)$ within the suboxic/hypoxic parts of the ACME is observed;

- sinking detritus and organic matter degradation might have contributed to the severe suboxia/hypoxia oxygen $<2 \mu \mathrm{mol} \mathrm{L}^{-1}$ ) in February 2010 in the subsurface waters. We assume that the severe suboxia began in early 2010 ;

- reduced daily migrating zooplankton in low oxygen eddies (Karstensen et al., 2015; Hauss et al., 2016) might have resulted in less organic matter degradation due to missing "flux feeding". This could have caused less organic carbon flux attenuation and, thus, a higher bathypelagic organic carbon flux.

\section{Conclusions and outlook}

The passage of a suboxic ACME across the CVOO site may be considered to be a natural experiment or open-ocean "mesocosm" with respect to particle sedimentation. Oxygen levels in the future oceans might decrease significantly and develop into OMZs due to increasing global warming and water column stratification (e.g. Stramma et al., 2008, 2010; Codispoti, 2010; Löscher et al., 2015a). These potential changes may in turn influence the nitrogen cycle and the operation of the biological pump, e.g. via a better preservation of organic materials due to reduced or non-existing microbial respiration (Iversen and Ploug, 2010) combined with reduced zooplankton activities (reduced "flux feeding") within developing OMZs. Such processes could enhance marine $\mathrm{CO}_{2}$ sequestration and operate as a negative feedback on global warming.

More intense studies on suboxic eddies could help to better understand warm periods in the Earth's history (e.g. the Upper Cretaceous), when OMZs were widely expanded and black shales deposited (e.g. Takashima et al., 2006; Schönfeld et al., 2015). Our study contributes to the unsolved question of production vs. preservation of organic debris when trying to explain the origin of black shales and oil source rocks in the Earth's history (e.g. Calvert, 1987). In addition, sedimentation signals with erratic character such as peaks in large diatoms in pelagic sediments below oligotrophic areas of the world ocean (e.g. Ethmodiscus rex in the South Atlantic, Romero and Schmieder, 2006) might be explained by processes occurring within recurring eddies. For instance, eddies released from the Agulhas Current system may serve as a productive oasis within generally oligotrophic ocean deserts and become suboxic/hypoxic at some time. This oxygen depletion may depend on the amount and type of settling organic-rich marine snow particles being remineralised in the subsurface waters (e.g. Löscher et al., 2015b; Karstensen et al., 2015) and on specific eddy physics as well.

Other remaining questions concerning the processes within suboxic/hypoxic eddies are

1. which processes trigger sedimentation? Are eddies characterised by pulsed sedimentation or quasicontinuous particle rain?

2. How frequent are these eddies on a global scale and which processes contribute to the development of hypoxia/suboxia in the subsurface waters?

3. What is the impact of the different groups of zooplankton (tolerating different oxygen levels) on particle flux and export within the eddies?

4. What is the contribution of different types of eddies (e.g. on an annual/seasonal basis) to carbon export and sedimentation at certain key locations and on a global scale?

Further studies are required for a better knowledge of eddy-induced processes in the surface (production) and subsurface waters (preservation), e.g. the observation and study of eddies when developing to suboxia/hypoxia, the changing $\mathrm{N}$ cycle, combined with measurements including the export into the epipelagic and the upper mesopelagic. The latter could be achieved, for instance, with free-drifting sediment traps equipped with optical instruments and/or neutrally buoyant sediment traps (e.g. Buesseler et al., 2007). In doing so, we can study organic carbon production vs. degradation processes with oxygen minima in more detail.

Author contributions. Gerhard Fischer wrote the manuscript, together with the co-authors, Johannes Karstensen designed the mooring, analysed the current meter data and contributed to writing as well, Oscar Romero studied the diatoms and contributed to the discussion, K.-H. Baumann studied the coccolithophores, Barbara Donner the planktonic foraminifera, Jens Hefter and Gesine Mollenhauer measured and interpreted the lipid biomarkers, Morten Iversen investigated the zooplankton, Björn Fielder the nitrogen cycle, and Ivanice Monteiro did the biogeochemistry at CVOO. Arne Körtzinger is coordinating the entire programme and contributed to the discussion.

Acknowledgements. We are grateful to G. Niehus and U. Papenburg (GEOMAR) for their help in the deployment of the mooring 
arrays at CVOO. We would like to thank the crews, masters and chief scientist Peter Brandt of l'Atalante 2008, MSM Merian 18/2 and RV Meteor 80/1 (all GEOMAR). At Marum, G. Ruhland and M. Klann were responsible for the preparation of the sediment traps and laboratory work. At the ZMT (Leibniz Center of Tropical Marine Ecology, Bremen), Dorothee Dasbach measured the stable nitrogen ratios; thanks also go to Birgit Mayer-Schack (marum) for sample preparation. This work was funded through the DFG Research Centers/Clusters of Excellence "The Ocean in the Earth System" at the Marum Centre of Marine Environmental Research, Bremen University, and "The Future Ocean" at the CAU, Kiel. Additional support was provided by DFG Collaborative Research Center 754 (www.sfb754.de). Satellite data were made available from the MODIS website (http://oceancolor.gsfc.nasa.gov/). CVOO is part of the OceanSITES network. We thank F. LeMoigne for detailed comments. Finally, we thank the reviewers C. Panagiotopoulos and D. Archer for constructive comments, suggestions and ideas to improve the manuscript. Thanks also to the associate editor of BG Special Issue (L. Cotrim da Cunha) for handling the manuscript.

The article processing charges for this open-access publication were covered by the University of Bremen.

Edited by: R. Conant

\section{References}

Altabet, M. and Deuser, W. G.: Seasonal variations in natural abundance of ${ }^{15} \mathrm{~N}$ in particles sinking to the deep Sargasso Sea, Nature, 315, 218-219, 1985.

Andruleit, H., Stäger, S. A., and Rogalle, U.: Living coccolithophores in the northern Arabian Sea: ecological tolerances and environmental control, Mar. Micropaleontol., 49, 157-181, 2003.

Ansmann, A., Petzold, A., Kandler, K., Tegen, I., Wendisch, M., Müller, D., Weinzierl, B., Müller, T., and Heintzenberg, J.: Saharan Mineral dust experiments SAMUM-1 and SAMUM-2: what have we learned?, Tellus, 63B, 403-429, 2011.

Armstrong, R. A., Lee, C., Hedges, J. I., Honjo, S., and Wakeham, S. G.: A new, mechanistic model of organic carbon fluxes in the ocean based on the quantitative association of POC with ballast minerals, Deep-Sea Res. Pt. II, 49, 219-236, 2002.

Ayon, P., Criales-Hernandez, M. I., Schwamborn, R., and Hirche, H.-J.: Zooplankton research off Peru: a review, Prog. Oceanogr., 79, 238-255, 2008.

Barton, E. D., Arístegui, J., Tett, P., Cantón, M., García-Braun, J., Hernández-León, S., Nykjaer, L., Almeida, C., Almunia, J., Ballesteros, S., Basterretxea, G., Escánez, J., García-Weill, L., Hernández-Guerra, A., López-Laatzen, F., Molina, P., Montero, M. F., Navarro-Pérez, E., Rodriguez, J. M., van Lenning, K., Vélez, H., and Wild, K.: Eastern Boundary of the North Atlantic: Northwest Africa and Iberia, in: The Global Coastal Ocean, edited by: Robinson, A. R. and Brink, K., John Wiley and Sons, New York, Chichester, Weinheim, Brisbane, Singapore, Toronto, Vol. 11, 29-67, 1998.

Benitez-Nelson, C. R. and McGillicuddy, D. J.: Mesoscale physicalbiological-biogeochemical linkages in the open ocean: An in- troduction to the results of the E-Flux and EDDIES programs, Deep-Sea Res. Pt. I, 55, 1133-1138, 2008.

Berelson, W. M.: Particle settling rates increase with depth in the ocean, Deep-Sea Res. Pt. II, 49, 237-251, 2002.

Berger, W. H. and Wefer, G.: Export production: seasonality and intermittency, and paleoceanographic implications, Palaeogeogr. Palaeocl., 89, 245-254, 1990.

Boeckel, B. and Baumann, K.-H.: Vertical and lateral variations in coccolithophore community structure across the subtropical frontal zone in the South Atlantic Ocean, Mar. Micropaleontol., 67, 255-273, 2008.

Bory, A., Jeandel, C., Leblond, N., Vangriesheim, A., Khripounoff, A., Beaufort, L., Rabouille, C., Nicolas, E., Tachikawa, K., Etcheber, H., and Buat-Menard, P.: Particle flux within different productivity regimes off the Mauritanian upwelling zone (EUMELI program), Deep-Sea Res. Pt. II, 48, 2251-2282, 2001.

Boyd, P. W. and Trull, T. W.: Understanding the export of biogenic particles in oceanic waters: is there a consensus?, Prog. Oceanogr., 72, 276-312, 2007.

Bressac, M., Guieu, C., Doxaran, D., Bourrin, F., Desboeufs, K., Leblond, N., and Ridame, C.: Quantification of the lithogenic carbon pump following a simulated dust-deposition event in large mesocosms, Biogeosciences, 11, 1007-1020, doi:10.5194/bg-11-1007-2014, 2014.

Buesseler, K. O., Antia, A. A., Chen, M., Fowler, S. W., Gardner, W. D., Gustafsson, O., Harada, K., Michaels, A. F., Rutgers van der Loeff, M., Sarin, M., Steinberg, D. K., and Trull, T.: An assessment of the use of sediment traps for estimating upper ocean particle fluxes, J. Mar. Res., 65, 345-416, 2007.

Calvert, S. E.: Oceanographic controls on the accumulation of organic matter in marine sediments, Geol. Soc. Spec. Publ., 26, 137-151, doi:10.1144/GSL.SP.1987.026.01.08, 1987.

Chang Y. and Yen, J.: Swimming in the Intermediate Reynolds Range: Kinematics of the Pteropod Limacina helicina, Integr. Comp. Biol., 52, 597-615, doi:10.1093/icb/ics113, 2012.

Chelton, D. B., Gaube, P., Schlax, M. G., Early, J. J., and Samelson, R. M.: The influence of nonlinear mesoscale eddies on near-surface chlorophyll, Science, 334, 328-332, doi:10.1126/science.1208897, 2011.

Codispoti, L. A.: Interesting times for marine $\mathrm{N}_{2} \mathrm{O}$, Science, 327, 1339-1340, doi:10.1126/science.1184945, 2010.

Conte, M. H., Sicre, M.-A., Rühlemann, C., Weber, J. C., Schulte, S., Schulz-Bull, D., and Blanz, T.: Global temperature calibration of the alkenone unsaturation index $\left(U_{37}^{k^{\prime}}\right)$ in surface waters and comparison with surface sediments, Geochem. Geophy. Geosy., 7, Q02005, doi:10.1029/2005GC001054, 2006.

Cropper, T. E., Hanna, E., and Bigg, G. R.: Spatial and temporal seasonal trends in coastal upwelling off Northwest Africa, 19812012, Deep-Sea Res. Pt. II, 86, 94-111, 2014.

Eltgroth, M. L., Watwood, R. L., and Wolfe, G. V.: Production and cellular localization of neutral long-chain lipids in the haptophyte algae Isochrysis galbana and Emiliania huxleyi, J. Phycol., 41, 1000-1009, 2005.

Ewart, C. S., Meyers, M. K., Wallner, E. R., McGillicuddy Jr., D. J., and Carlson, C. A.: Microéial Dynamics in Cyclonic and Anticyclonic Mode-Water Eddies in the Northwestern Sargasso Sea, Deep-Sea Res. Pt. II, 55, 1334-1347, 2008.

Fiedler, B., Grundle, D., Schütte, F., Karstensen, J., Löscher, C. R., Hauss, H., Wagner, H., Loginova, A., Kiko, R., Silva, P., and 
Körtzinger, A.: Oxygen Utilization and Downward Carbon Flux in an Oxygen-Depleted Eddy in the Eastern Tropical North Atlantic, Biogeosciences Discuss., doi:10.5194/bg-2016-23, in review, 2016.

Fischer, G. and Karakas, G.: Sinking rates and ballast composition of particles in the Atlantic Ocean: implications for the organic carbon fluxes to the deep ocean, Biogeosciences, 6, 85102, doi:10.5194/bg-6-85-2009, 2009.

Fischer, G. and Wefer, G.: Sampling, preparation and analysis of marine particulate matter, in: Marine particles: Analysis and Characterization, edited by: Hurd, D. C. and Spencer, D. W., AGU Monograph Series, 63, Washington, DC, 391-397, 1991.

Fischer, G., Wefer, G., Romero, O., Dittert, N., Ratmeyer, V., and Donner, B.: Transfer of particles into the deep Atlantic and the global Ocean: control of nutrient supply and ballast production. In: The South Atlantic in the Late Quaternary: Reconstruction of material budget and current systems, edited by: Wefer, G., Mulitza, S., and Ratmeyer, V., Springer, Berlin, Heidelberg, New York, 21-46, 2003.

Fischer, G., Karakas, G., Blaas, M., Ratmeyer, V., Nowald, N., Schlitzer, R., Helmke, P., Davenport, R., Donner, B., Neuer, S., and Wefer, G.: Mineral ballast and particle settling rates in the coastal upwelling system off NW Africa and the South Atlantic, Int. J. Earth Sci., 98, 281-298, doi:10.1007/s00531-007-0234-7, 2009a.

Fischer, G., Reuter, C., Karakas, G., Nowald, N., and Wefer, G.: Offshore advection of particles within the Cape Blanc filament, Mauritania: results from observational and modelling studies, Prog. Oceanogr., 83, 322-330, 2009b.

Fischer, G., Neuer, S., Davenport, R., Romero, O., Ratmeyer, V., Donner, B., Freudenthal, T., Meggers, H., and Wefer, G.: The Northwest African Margin, in: Carbon and Nutrient Fluxes in Continental Margins: A Global Synthesis, edited by: Liu, K. K., Atkinson, L., Quinones, R., and Talaue-McManaus, L., IGBP Book Series, Springer, Berlin, 77-103, 2010.

Fomba, K. W., Müller, K., van Pinxteren, D., Poulain, L., van Pinxteren, M., and Herrmann, H.: Long-term chemical characterization of tropical and marine aerosols at the Cape Verde Atmospheric Observatory (CVAO) from 2007 to 2011, Atmos. Chem. Phys., 14, 8883-8904, doi:10.5194/acp-14-8883-2014, 2014.

Fréon, P., Arístegui, J., Bertrand, A., Crawford, R. J. M., Field, J. C., Gibbons, M. J., Tam, J., Hutchings, L., Masski, H., Mullon, C., Ramdani, M., Seret, B., and Simier, M.: Functional group biodiversity in Eastern Boundary Upwelling Ecosystems questions the wasp-waist trophic structure, Prog. Oceanogr., 83, 97-106, 2009.

Gama, C., Tchepel, O., Baldasano, J. M., Basart, S., Ferreira, J., Pio, C., Cardoso, J., and Borrego, C.: Seasonal patterns of Saharan dust over the Cape Verde - a combined approach using observations and modelling, Tellus B, 67, 24410, doi:10.3402/tellusb.v67.24410, 2015.

Goudie, A. S. and Middleton, N. J.: Saharan dust storms: nature and consequences, Earth Sci. Rev., 56, 179-204, 2001.

Hagino, K. and Okada, H.: Intra- and infra-specific morphological variation in selected coccolithophore species in the equatorial and subequatorial Pacific Ocean, Mar. Micropaleontol., 58, 184-206, 2006.
Hagino, K., Okada, H., and Matsuoka, H.: Spatial dynamics of coccolithophore assemblages in the equatorial western-central $\mathrm{Pa}$ cific Ocean, Mar. Micropaleontol., 39, 53-57, 2000.

Haidar, A. T. and Thierstein, H. R.: Coccolithophore dynamics off Bermuda (N. Atlantic), Deep-Sea Res. Pt. II, 48, 1925-1956, 2001.

Hauss, H., Christiansen, S., Schütte, F., Kiko, R., Edvam Lima, M., Rodrigues, E., Karstensen, J., Löscher, C. R., Körtzinger, A., and Fiedler, B.: Dead zone or oasis in the open ocean? Zooplankton distribution and migration in low-oxygen modewater eddies, Biogeosciences, 13, 1977-1989, doi:10.5194/bg-13-1977-2016, 2016.

Hedges, J. I.: Global biogeochemical cycles: Progress and problems, Mar. Chem., 39, 67-93, 1992.

Helmke, P., Romero, O., and Fischer, G.: Northwest African upwelling and its effect on off-shore organic carbon export to the deep sea, Global Biogeochem. Cy., 19, GB4015, doi:10.1029/2004GB002265, 2005.

Hemleben, C., Spindler, M., and Anderson, O. R.: Modern Planktonic Foraminifera, Springer Verlag, Heidelberg, New York, 363 pp., 1989.

Honjo, S. and Okada, H.: Community structure of coccolithophores in the photic layer of the mid-Pacific, Micropaleontology, 29, 209-230, 1974.

Honjo, S., Manganini, S. J., Krishfield, R. A., and Francois, R.: Particulate organic carbon fluxes to the ocean interior and factors controlling the biological pump. A synthesis of global sediment trap programs since 1983, Prog. Oceanogr., 76, 217-285, 2008.

Ittekkot, V.: The abiotically driven biological pump in the ocean and short-term fluctuations in atmospheric $\mathrm{CO}_{2}$ contents, Global Planet. Change, 8, 17-25, 1993.

Iversen, M. H. and Ploug, H.: Ballast minerals and the sinking carbon flux in the ocean: carbon-specific respiration rates and sinking velocity of marine snow aggregates, Biogeosciences, 7 , 2613-2624, doi:10.5194/bg-7-2613-2010, 2010.

Iversen, M. H. and Ploug, H.: Temperature effects on carbonspecific respiration rate and sinking velocity of diatom aggregates - potential implications for deep ocean export processes, Biogeosciences, 10, 4073-4085, doi:10.5194/bg-10-4073-2013, 2013.

Iversen, M. H. and Robert, M. L.: Ballasting effects of smectite on aggregate formation and export from a natural plankton community, Mar. Chem., 175, 18-27, 2015.

Iversen, M. H., Nowald, N., Ploug, H., Jackson, G. A., and Fischer, G.: High resolution profiles of vertical particulate organic matter export off Cape Blanc, Mauritania: Degradation processes and ballasting effects, Deep-Sea Res. Pt. I, 57, 771-784, 2010.

Jickells, T. D., Dorling, S., Deuser, W. G., Church, T. M., Armoto, R., and Prospero, J. M.: Air-borne dust fluxes to a deep water sediment trap in the Sargasso Sea, Global Biogeochem. Cy., 12, 311-320, 1998.

Jordan, R. W. and Chamberlain, A. H. L.: Biodiversity among haptophyte algae, Biodivers. Conserv., 6, 131-152, 1997.

Karl, D., Christian, J. R., Dore, J. E., Hebel, D. V., Letelier, R. M., Tupas, L. M., and Winn, C. D.: Seasonal and interannual variability in primary production and particle flux at Station Aloha, Deep-Sea Res. Pt. II, 43, 539-568, 1996.

Karstensen, J., Fiedler, B., Schütte, F., Brandt, P., Körtzinger, A., Fischer, G., Zantopp, R., Hahn, J., Visbeck, M., and Wallace, 
D.: Open ocean dead zones in the tropical North Atlantic Ocean, Biogeosciences, 12, 2597-2605, doi:10.5194/bg-12-2597-2015, 2015.

Karstensen, J., Schütte, F., Pietri, A., Krahmann, G., Fiedler, B., Grundle, D., Hauss, H., Körtzinger, A., Löscher, C. R., Testor, P., Vieira, N., and Visbeck, M.: Upwelling and isolation in oxygendepleted anticyclonic modewater eddies and implications for nitrate cycling, Biogeosciences Discuss., doi:10.5194/bg-2016-34, in review, 2016.

Kaufman, Y. J., Koren, I., Remer, L. A., Tanré, D., Ginoux, P., and Fan, S.: Dust transport and deposition from the Terra-Moderate Resolution Imaging Spectroradiometer (MODIS) spacecraft over the Atlantic Ocean, J. Geophys. Res., 110, D10S12, doi:10.1029/2003JD004436, 2005.

Koopmans, M. P., Koster, J., Van Kaam-Peters, H. M. E., Kenig, F., Schouten, S., Hartgers, W. M., De Leeuw, J. W., and Sinninghe Damsté, J. S.: Diagenetic and catagenetic products of isorenieratene: Molecular indicators for photic zone anoxia, Geochim. Cosmochim. Acta, 60, 4467-4496, 1996.

Kremling, K., Lentz, U., Zeitzschell, B., Schulz-Bull, D. E., and Duinker, J. C.: New type of time-series sediment trap for the reliable collection of inorganic and organic trace chemical substances, Rev. Sci. Instrum., 67, 4360-4363, 1996.

Kucera, M.: Planktonic Foraminifera as Tracers of Past Oceanic Environments, in: Proxies in Late Cenozoic Paleoceanography, edited by: Hillaire-Marcel, C. and de Verna, A., Elsevier, Amsterdam, Vol. 1, 213-262, 2007.

Lampitt, R. S. and Antia, A. N.: Particle flux in deep seas: regional characteristics and temporal variability, Deep-Sea Res. Pt. I, 44, 1377-1403, 1997.

Laws, E. E. and Bannister, T. T.: Nutrient- and light-limited growth of Thalassiosira fluviatilis in continuous culture, with implications for phytoplankton growth in the ocean, Limnol. Oceanogr., 25, 457-473, 1980.

Le Moigne, F. A. C., Pabortsava, K., Marcinko, C. L. J., Martin, P., and Sanders, R. J.: Where is mineral ballast important for surface export of particulate organic carbon in the ocean?, Geophys. Res. Lett., 41, 8460-8468, doi:doi:101002/2014GL061678, 2014.

Libes, S. M. and Deuser, W. G.: The isotopic geochemistry of particulate nitrogen in the Peru Upwelling Area and the Gulf of Maine, Deep-Sea Res. Pt. I, 35, 517-533, 1988.

Liu, K. K. and Kaplan, I. R.: The eastern tropical Pacific as a source of ${ }^{15} \mathrm{~N}$-enriched nitrate in seawater off southern California, Limnol. Oceanogr., 34, 820-830, 1989.

Loebl, M., Cockshutt, A. M., Campbell, D. A., and Finkel, Z. V.: Physiological basis for high resistance to photoinhibition under nitrogen depletion in Emiliania huxleyi, Limnol. Oceanogr., 55, 2150-2160, doi:10.4319/lo.2010.55.5.2150, 2010.

Löscher, C. R., Bange, H. W., Schmitz, R. A., Callbeck, C. M., Engel, A., Hauss, H., Kanzow, T., Kiko, R., Lavik, G., Loginova, A., Melzner, F., Neulinger, S. C., Pahlow, M., Riebesell, U., Schunck, H., Thomsen, S., and Wagner, H.: Water column biogeochemistry of oxygen minimum zones in the eastern tropical North Atlantic and eastern tropical South Pacific Oceans, Biogeosciences Discuss., 12, 4495-4556, doi:10.5194/bgd-12-44952015, 2015a.

Löscher, C. R., Fischer, M. A., Neulinger, S. C., Fiedler, B., Philippi, M., Schütte, F., Singh, A., Hauss, H., Karstensen, J., Körtzinger, A., Künzel, S., and Schmitz, R. A.: Hidden biosphere in an oxygen-deficient Atlantic open-ocean eddy: future implications of ocean deoxygenation on primary production in the eastern tropical North Atlantic, Biogeosciences, 12, 7467-7482, doi:10.5194/bg-12-7467-2015, 2015 b.

Luyten, J. R., Pedlowski, J., and Stommel, H.: The ventilated thermocline, J. Phys. Oceanogr., 13, 292-309, 1983.

Malinverno, E., Ziveri, P., and Corselli, C.: Coccolithophorid distribution in the Ionian Sea and its relationship to eastern Mediterranean circulation during late fall to early winter 1997, J. Geophys. Res., 108, 8115, doi:10.1029/2002JC001346, 2003.

Martiny, A. C., Pham, C. T. A., Primeau, F. W., Vrugt, J. A., Moore, J. K., Levin, S. A., and Lomas, M. W.: Strong latitudinal patterns in the elemental ratios of marine plankton and organic matter, Nat. Geosci., 6, 279-283, 2013.

McGillicuddy, D. J., Anderson, L. A., Bates, N. R., Bibby, T., Buesseler, K. O., Carlson, C. A., Davis, C. S., Ewart, C., Falkowski, P. G., Goldthwait, S. A., Hansell, D. A., Jenkins, W. J., Johnson, R., Kosnyrev, V. K., Ledwell, J. R., Li, Q. P., Siegel, D. A., and Steinberg, D. K.: Eddy/wind interactions stimulate extraordinary mid-ocean plankton blooms, Science, 316, 1021-1026, doi:10.1126/science.1136256, 2007.

McNeil, J. D., Jannasch, H. W., Dickey, T., McGillicuddy, D., Brzezinski, M., and Sakamoto, C. M.: New chemical, bio-optical and physical observations of upper ocean response to the passage of a mesoscale eddy off Bermuda, J. Geophys. Res.-Oceans, 104, 15537-15548, 1999.

Müller, P. J. and Schneider, R.: An automated leaching method for the determination of opal in sediments and particulate matter, Deep-Sea Res. Pt. I, 40, 425-444, 1993.

Moulin, C., Lambert, C. E., Dulac, F., and Dayan, U.: Control of atmospheric export of dust from North Africa by the North Atlantic Oscillation, Nature, 387, 691-694, 1997.

Neuer, S., Cianca, A., Helmke, P., Freudenthal, T., Davenport, R., Meggers, H., Knoll, M., Santana-Casiano, J. M., GonzálezDavila, M., Rueda, M.-J., and Llinás, O.: Biogeochemistry and hydrography in the eastern subtropical North Atlantic gyre. Results from the European time-series station ESTOC, Prog. Oceanogr., 72, 1-29, 2007.

Ploug, H., Iversen, M. H., and Fischer, G.: Ballast, sinking velocity, and apparent diffusivity within marine snow and fecal pellets: Implications for substrate turnover by attached bacteria, Limnol. Oceanogr., 53, 1878-1886, 2008.

Prahl, F. G. and Wakeham, S. G.: Calibration of unsaturation patterns in long-chain ketone compositions for palaeotemperature assessment, Nature, 330, 367-369, 1987.

Prahl, F. G., Wolfe, G. V., and Sparrow, M. A.: Physiological impacts on alkenone paleothermometry, Paleoceanography, 18, 1025, doi:10.1029/2002PA000803, 2003.

Ratmeyer, V., Balzer, W., Bergametti, G., Chiapello, I., Fischer, G., and Wyputta, U.: Seasonal impact of mineral dust on deepocean particle flux in the eastern subtropical Atlantic Ocean, Mar. Geol., 159, 241-252, 1999.

Redfield, A. C., Ketchum, B. H., and Richards, F. A.: The influence of organisms on the composition of seawater, in: The Sea, edited by: Hill, M. N., Vol. 2, Wiley and Sons, Chichester, 26-77, 1963.

Romankevich, E. A.: Geochemistry of OM in the Ocean, Springer, Berlin, Heidelberg, New York, 334 pp., 1984.

Romero, O., Crosta, E. X., Kim, J.-H., Pichevin, L., and Crespin, J.: Rapid longitudinal migrations of the filament front off Namibia 
(SE Atlantic) during the past $70 \mathrm{kyr}$, Global Planet. Change, 125, $1-12,2015$.

Romero, O. E. and Armand, L. K.: Marine diatoms as indicators of modern changes in oceanographic conditions, in: The Diatoms, Applications for the Environmental and Earth Sciences, Second Edn., edited by: Smol, J. P. and Stoermer, E. F., Cambridge University Press, Cambridge, 373-400, 2010.

Romero, O. E. and Schmieder, F.: Occurrence of thick Ethmodiscus oozes associated with a terminal Mid-Pleistocene Transition event in the oligotrophic subtropical South Atlantic, Palaeogeogr. Palaeocl., 235, 321-329, 2006.

Romero, O. E., Lange, C. B., and Wefer, G.: Interannual variability (1988-1991) of siliceous phytoplankton fluxes off northwest Africa, J. Plankton Res., 24, 1035-1046, 2002.

Round, F. E., Crawford, R. M., and Mann, D. G.: The diatoms, Cambridge University Press, Cambridge, 747 pp., 1990.

Saino, T. and Hattori, A.: Geographical variation of the water column distribution of suspended particulate organic nitrogen and its ${ }^{15} \mathrm{~N}$ natural abundance in the Pacific and its marginal seas, Deep-Sea Res. Pt. I, 34, 807-827, 1987.

Sancetta, C. and Calvert, S. E.: The annual cycle of sedimentation in Saanich Inlet, British Columbia: implications for the interpretation of diatom fossil assemblages, Deep-Sea Res. Pt. I., 35, 7190, 1988.

Schepanski, K., Tegen, I., and Macke, A.: Saharan dust transport and deposition towards the tropical northern Atlantic, Atmos. Chem. Phys., 9, 1173-1189, doi:10.5194/acp-9-1173-2009, 2009.

Schönfeld, J., Kuhnt, W., Erdem, Z., Flögel, S., Glock, N., Aquit, M., Frank, M., and Holbourn, A.: Records of past mid-depth ventilation: Cretaceous ocean anoxic event 2 vs. Recent oxygen minimum zones, Biogeosciences, 12, 1169-1189, doi:10.5194/bg12-1169-2015, 2015.

Schrader, H.-J. and Gersonde, R.: Diatoms and silicoflagellates, Utrecht Micropaleontological Bulletin, in: Micropaleontological counting methods and techniques - an exercise on an eight meter section of the Lower Pliocene of Capo Rosello, Sicily, edited by: Zachariasse, W. J., Riedel, W. R., Sanfilippo, A., Schmidt, R. R., Brolsma, M. J., Schrader, H., Gersonde, R., Drooger, M. M., and Broekman, J. A., Utrecht, 17, 129-176, 1978.

Schütte, F., Brandt, P., and Karstensen, J.: Occurrence and characteristics of mesoscale eddies in the tropical northeastern Atlantic Ocean, Ocean Sci., 12, 663-685, doi:10.5194/os-12-663-2016, 2016a.

Schütte, F., Karstensen, J., Krahmann, G., Hauss, H., Fiedler, B., Brandt, P., Visbeck, M., and Körtzinger, A.: Characterization of "dead-zone" eddies in the tropical Northeast Atlantic Ocean, Biogeosciences Discuss., doi:10.5194/bg-2016-33, in review, 2016b.

Schütz, L., Jaenicke, R., and Pietreck, H.: Saharan dust transport over the North Atlantic Ocean: model calculations and measurements, in: Desert Dust, edited by: Péwé, T. L., Geol. Soc. Amer. Spec. Publ., 186, 87-100, 1981.
Siegel, D. A. and Deuser, W. G.: Trajectories of sinking particles in the Sargasso Sea: modeling of statistical funnels above deepocean sediment traps, Deep-Sea Res. Pt. I, 44, 1519-1541, 1997.

Sikes, E. L., O'Leary, T., Nodder, S. D., and Volkman, J. K.: Alkenone temperature records and biomarker flux at the subtropical front on the Chatham Rise, SW Pacific Ocean, Deep-Sea Res. Pt. I, 52, 721-748, doi:10.1016/j.dsr.2004.12.003, 2005.

Sinninghe Damsté, J. S., Strous, M., Rijpstra, W. I. C., Hopmans, E. C., Geenevasen, J. A. J., van Duin, A. C. T., van Niftrik, L. A., and Jetten, M. S. M.: Linearly concatenated cyclobutane lipids form a dense bacterial membrane, Nature, 419, 708-712, 2002.

Stramma, L., Johnson, G. C., Sprintall, J., and Mohrholz, V.: Expanding oxygen-minimum zones in the Tropical Oceans, Science, 320, 655-658, 2008.

Stramma, L., Schmidtko, S., Levin, L. A., and Johnson, G. C.: Ocean oxygen minima expansions and their biological impacts, Deep-Sea Res. Pt. I, 57, 587-595, doi:10.1016/j.dsr.2010.01.005, 2010.

Sweeney, E. N., McGillicuddy, D. J., and Buesseler, K. O.: Biogeochemical impacts due to mesoscale eddy activity in the Sargasso Sea as measured at the Bermuda Atlantic Time Series Study (BATS), Deep-Sea Res. Pt. II, 50, 3017-3039, 2003.

Takahashi, K. and Okada, H.: Environmental control on the biogeography of modern coccolithophores in the southeastern Indian Ocean offshore of Western Australia, Mar. Micropaleontol., 39, 73-86, 2000.

Takashima, R., Hishi, H., Huber, B., and Leckie, M.: Greenhouse world and the Mesozoic ocean, Oceanography, 19, 82-92, 2006.

Tyson, R. V.: Sedimentary OM: organic facies and palynofacies, Chapman and Hall, London, 615 pp., 1995.

Van Camp, L., Nykjaer, L., Mittelstaedt, E., and Schlittenhardt, P.: Upwelling and boundary circulation off Northwest Africa as depicted by infrared and visible satellite observations, Prog. Oceanogr., 26, 357-402, 1991.

Wagner, T. and Dupont, L. M.: Terrestrial organic matter in marine sediments: analytical approaches and eolian-marine records in the Central Equatorial Atlantic, in: Use of proxies in Paleoceanography: Examples from the South Atlantic, edited by: Fischer, G. and Wefer, G., Springer, Berlin, Heidelberg, 547-574, 1999.

Yu, E. F., Francois, R., Honjo, S., Fleer, A. P., Manganini, S. J., Rutgers van der Loeff, M. M., and Ittekkot, V.: Trapping efficiency of bottom-tethered sediment traps estimated from the intercepted fluxes of ${ }^{230} \mathrm{Th}$ and ${ }^{231} \mathrm{~Pa}$, Deep-Sea Res. Pt. I, 48, 865-889, 2001.

Zenk, W., Klein, B., and Schroder, M.: Cape Verde Frontal Zone, Deep-Sea Res. Pt. I, 38, Supplement 1, 505-530, 1991. 